
\title{
3 Research Square \\ Characterisation and structural analysis of glyoxylate cycle enzymes of Teladorsagia circumcincta.
}

Saleh Umair

AgResearch Ltd

Charlotte Bouchet

AgResearch Ltd

Nikola Palevich ( $\square$ nik.palevich@agresearch.co.nz)

AgResearch Ltd

Heather Simpson

Massey University

\section{Research Article}

Keywords: Cloning, ELISA, Expression, Isocitrate lyase, Kinetic properties, Malate synthase, Teladorsagia circumcincta

Posted Date: October 8th, 2020

DOI: https://doi.org/10.21203/rs.3.rs-88851/v1

License: (c) (i) This work is licensed under a Creative Commons Attribution 4.0 International License. Read Full License

Version of Record: A version of this preprint was published at Molecular and Biochemical Parasitology on November 1st, 2020. See the published version at https://doi.org/10.1016/j.molbiopara.2020.111335. 

circumcincta

* Corresponding author 
A 1332 bp full length cDNA encoding Teladorsagia circumcincta isocitrate lyase (TciICL) and a $1575 \mathrm{bp}$ full length cDNA encoding $T$. circumcincta malate synthase (TciMS) were cloned, expressed in Escherichia coli and the recombinant proteins purified. The predicted TciICL protein of 444 amino acids was present as a single band of about $52 \mathrm{kDa}$ on SDS-PAGE and the recombinant TciMS of 525 amino acids formed a single band about $62 \mathrm{kDa}$. Multiple alignments of the combined bifunctional TciICLMS protein sequence with homologues from other nematodes showed that the greatest similarity (89-92\%) to the homologues of Ancylostoma ceylanicum, Haemonchus contortus and Haemonchus placei and $71-87 \%$ similarity to the other nematode sequences. The 3-dimensional structures, binding and catalytic sites were determined for $T c i \mathrm{ICL}$ and $T c i \mathrm{MS}$ and shown to be highly conserved. Substrate and metal ion binding sites were identified and were completely conserved in other homologues. TciICL was confirmed as a functional enzyme. At $30^{\circ} \mathrm{C}$, the optimum $\mathrm{pH}$ was $\mathrm{pH} 7.5$, the $\mathrm{V}_{\max }$ was $275 \pm 23$ nmoles. $\mathrm{min}^{-1} \cdot \mathrm{mg}^{-1}$ protein and the apparent $\mathrm{K}_{\mathrm{m}}$ for the substrate isocitrate was $0.7 \pm 0.01 \mu \mathrm{M}$ (mean $\pm \mathrm{SEM}, \mathrm{n}=3$ ). Addition of $10 \mathrm{mM}$ metal ions (except $\mathrm{Mg}^{2+}$ ) or $1 \mathrm{mM}$ inhibitors reduced the recombinant Tci ICL activity by $60-90 \%$. Antibodies in both serum and saliva from field-immune, but not nematode-naïve, sheep recognised recombinant TciICL in ELISA, supporting similar antigenicity to that of the native enzyme. synthase; Teladorsagia circumcincta 


\section{Introduction}

The glyoxylate cycle (GC) converts isocitrate to malate in a two enzyme shunt which is an alternative to the full TCA cycle [1]. The GC allows net conversion of lipid to carbohydrate, as it bypasses the two $\mathrm{CO}_{2}$-generating decarboxylations in the conversion of isocitrate to succinate in the TCA cycle. The GC consists of the two enzymes isocitrate lyase (ICL) (EC 4.1.3.1) and malate synthase (MS) (EC 2.3.3.9): ICL cleaves isocitrate to glyoxylate and succinate, followed by MS condensing glyoxylate with acetyl CoA to form malate and coenzymeA [1]. In the TCA cycle, isocitrate is the substrate for isocitrate dehydrogenase (ICD) and later malate is generated by fumarase; $\mathrm{CO}_{2}$ is generated at the steps catalysed by ICD and glutamate dehydrogenase (GDH).

This shunt is active in bacteria, fungi, nematodes and plants, and the enzymes are reported to be inducible under specific conditions in other groups of animals under stress conditions $[2,3]$. In nematodes, enzyme activity has been measured in several freeliving species [4-6] and the animal parasitic Ascaris lumbricoides [7], Ascaris suum [8] and Haemonchus contortus [9]. In nematodes, there is a bifunctional ICL-MS gene, which has been sequenced and expressed in a number of species, including Caenorhabditis elegans [10] and Strongyloides stercoralis [11] and other sequences are available in databases.

There is greater GC activity in nematodes when lipid reserves are being used in non-feeding stages and eggs $[12,13]$, during embryonic development $[6,9]$ and when trehalose accumulates to tolerate desiccation or freezing [14-16]. Knockdown of ICL by RNAi reduced egg production in the plant parasitic Meloidogyne incognita [17]. The relative flows of carbon in the mitochondria through the GC and TCA cycles are determined by competition for the substrate isocitrate by ICL and isocitrate 
dehydrogenase (IDH) and the activities and properties of these two enzymes [2]. Coarse control of flux is determined by transcription and synthesis of the enzymes according to the metabolic environment, such as during development through the life-cycle [13] and formation of dauer larvae [18]. Fine rapid control is through variation in $\mathrm{K}_{\mathrm{m}}$, specific activity and number of multiple forms of the enzyme [14, 19]. Madin et al. [14] showed that early in desiccation the isocitrate concentration rose, saturating IDH with its 40-fold lower $\mathrm{K}_{\mathrm{m}}$ than that of ICL. The $\mathrm{V}_{\max }$ of IDH progressively fell, resulting in a reduced flux through IDH and the TCA cycle and a relatively higher flux through ICL and the GC shunt. Changes in cellular pH could affect enzyme activities, as the ICL of nematodes have $\mathrm{pH}$ optima of 7.4-7.7, lower than that for IDH [7, 20].

The aim of the present experiments was to determine the full length sequence of ICL-MS in the sheep abomasal nematode parasite Teladorsagia circumcincta, express the proteins and determine kinetic properties and antigenicity of the recombinantly produced enzyme.

\section{Materials and methods}

All chemicals were purchased from the Sigma Chemical Co. (Mo, USA) unless stated otherwise. Use of experimental animals for culturing and harvesting adult worms for RNA extraction has been approved by the AgResearch Grasslands Animal Ethics Committee (protocol \#13052).

\subsection{Parasites}

Pure cultures of $T$. circumcincta were maintained in the laboratory by regular passage through sheep. Adult worms were recovered from the abomasa of infected sheep 
as described previously [21]. Briefly, abomasal contents were mixed 2:1 with 3\% agar and the solidified agar blocks incubated at $37^{\circ} \mathrm{C}$ in a saline bath. Clumps of parasites were collected from the saline soon after emergence and frozen in Eppendorff tubes at $80{ }^{\circ} \mathrm{C}$ for molecular biology procedures.

\subsection{RNA isolation and cDNA synthesis}

Adult T. circumcincta (50-100 $\mu \mathrm{l}$ packed volume) in $1 \mathrm{ml}$ Trizol (Life Technologies) were ground to a fine powder in a mortar under liquid $\mathrm{N}_{2}$ and RNA extracted according to the manufacturer's instructions. The quality and concentration of the RNA was assessed using Nanodrop. First strand cDNA synthesised from $1 \mathrm{ug}$ using the iScript Select cDNA Synthesis Kit (Bio-Rad) and a 1:1 mixture of Oligo (dT) 20 and random primers. As ICL-MS is one large bifunctional protein, ICL and MS were expressed and characterised as separate proteins. Primers were designed to obtain the full-length sequences using two partial T. circumcincta ICL-MS sequences: TDC00774 in NEMBASE and TELCIR_04692 in AgResearch's internal database.

The full length TciICL or TciMS cDNA was amplified from total $T$. circumcincta cDNA in a PCR containing either the oligonucleotide primers TciICL_FL-F (5'- CATGGGCGCGCCATGGCGCAGGCCGCTAAGAAC-3') and

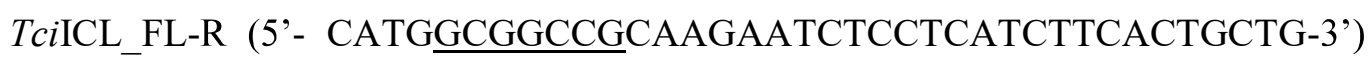

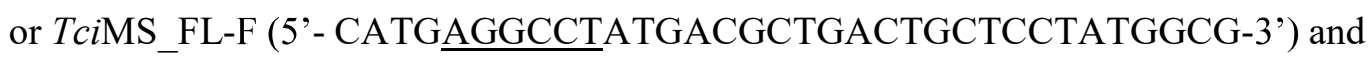
TciMS_FL-R (5'- CATGGCGGCCGCGTGTCCTTCTGATACCAGCTTGTC-3') respectively. The full length genes were cloned, using standard protocols, into the expression vector AY2.4 [22], using the restriction enzymes Ascl and Notl for TciICL and Stu1 and NOT1 for TciMS (engineered into the forward and reverse primers, 
underlined in the primer sequences) to allow the production of $\mathrm{N}$-terminal His-tagged recombinant protein. The expression clones were sequenced to confirm identity.

Alignments were performed using the Muscle alignment option in Geneious

\subsection{Protein modelling and structural analysis of TciICL and TciMS}

The Position-Specific Iterative Basic Local Alignment Search Tool (PSIBLAST) [23] was used to compare the TciICL and TciMS protein sequences with deposited structures in the Protein Data Bank (PDB). The structural models of TciICL and TciMS were constructed by submitting the amino acid sequences obtained as described above, to the I-TASSER server [24]. For TciMS, only one model was obtained and for TciICL a model was selected from the best of five possible models generated. The structural model with the highest C-score was further validated using Procheck [25] and ProSA-web [26]. TM-score is a metric for measuring the similarity of two protein structures, or a global fold similarity between the generated model and the structure it was based on. Scores higher than 0.5 assumes the parent structure and modelled protein share the same fold while below 0.17 suggests a random nature to the produced model [27]. C-score is a confidence score for estimating the quality of predicted models by ITASSER. It is calculated based on the significance of threading template alignments and the convergence parameters of the structure assembly simulations. C-score is typically in the range of -5 to 2 , where a $\mathrm{C}$-score of higher value signifies a model with a high confidence and vice-versa. The substrate binding domains were predicted, and active site residues deduced using the PyMOL Molecular Graphics System, Version 2.0 (Schrödinger, LLC). 
For the expression of TcilCL, Escherichia coli strain BL21 (DE3) was transformed with E. coli AY2.4 TciICL and grown in $10 \mathrm{ml}$ Luria Broth (LB), supplemented with $100 \mu \mathrm{g} / \mathrm{ml}$ ampicillin, for $16 \mathrm{~h}$ at $30{ }^{\circ} \mathrm{C}$ and $250 \mathrm{rpm}$. The culture was diluted 20 -fold in LB with $100 \mu \mathrm{g} / \mathrm{ml}$ ampicillin and grown at $37{ }^{\circ} \mathrm{C}$ and $250 \mathrm{rpm}$ to an $\mathrm{OD}_{600}$ of $0.6-0.8$. L-arabinose was added to a final concentration of $0.2 \%$ and the culture grown for an additional $4 \mathrm{~h}$ at $30{ }^{\circ} \mathrm{C}$ and $250 \mathrm{rpm}$. Bacteria were harvested by centrifugation at 5,000 $\mathrm{g}$ for $10 \mathrm{~min}$ at $4{ }^{\circ} \mathrm{C}$. The pellet was weighed and the bacteria resuspended $(10 \mathrm{~g} / \mathrm{ml})$ in equilibration buffer $(20 \mathrm{mM}$ sodium biphosphate, $0.5 \mathrm{M} \mathrm{NaCl}$, $20 \mathrm{mM}$ imidazole, $\mathrm{pH}$ 7.4). Protease inhibitors were added to the suspension, which was then passed through the chamber of a MP110 Microfluidizer ${ }^{\circledR}$ (Microfluidics, USA) seven times consecutively under ice at 20,000 psi to ensure the full lysis of E.coli, as recommended by the manufacturer. The crude lysate was centrifuged at $15,000 \mathrm{~g}$ for 20 min at $4{ }^{\circ} \mathrm{C}$ to remove cell debris and the supernatant filtered through a $0.22 \mu \mathrm{m}$ filter prior to purification.

TciMS was expressed in E. coli strain BL21 (DE3), transformed with E. coli Rosetta gami TciMS, and grown in $10 \mathrm{ml}$ LB supplemented with $100 \mu \mathrm{g} / \mathrm{ml}$ ampicillin, kanamycin $50 \mu \mathrm{g} / \mathrm{ml}$, chloramphenicol $34 \mu \mathrm{g} / \mathrm{ml}$ and tetracycline $12.5 \mu \mathrm{g} / \mathrm{ml}$ for $16 \mathrm{~h}$ at $37{ }^{\circ} \mathrm{C}$ and $250 \mathrm{rpm}$. The culture was diluted 20 -fold in LB with $100 \mu \mathrm{g} / \mathrm{ml}$ ampicillin, kanamycin $50 \mu \mathrm{g} / \mathrm{ml}$, chloramphenicol $34 \mu \mathrm{g} / \mathrm{ml}$ and tetracycline $12.5 \mu \mathrm{g} / \mathrm{ml}$ and grown to an $\mathrm{OD}_{600}$ of $0.6-0.8$ at $37{ }^{\circ} \mathrm{C}$ and $250 \mathrm{rpm}$. L-arabinose was added to a final concentration of $0.2 \%$ and the culture grown for an additional $16 \mathrm{~h}$ at $37{ }^{\circ} \mathrm{C}$ and 250 rpm.

Recombinant TciMS was expressed as a totally insoluble protein which was purified and folded as inclusion bodies. Briefly, bacteria were harvested by centrifugation, the 
supernatant was discarded and the pellet resolubilised in binding buffer $(1 \mathrm{ml} / 10 \mathrm{mg})$ containing $8 \mathrm{M}$ urea. Protease inhibitors were added at room temperature for $10 \mathrm{~min}$. The lysate was centrifuged at $16,000 \mathrm{~g}$ for $10 \mathrm{~min}$ at $4{ }^{\circ} \mathrm{C}$ to remove cell debris and the supernatant was collected and filtered through a $0.45 \mu \mathrm{m}$ filter.

\subsection{Purification of recombinant TciICL and TciMS}

Purified recombinant poly-histidine TciICL was obtained by Fast Protein Liquid Chromatography (FPLC) under native conditions using a Ni-NTA column (Qiagen) and a BIO-RAD chromatography system (Bio-Rad, USA). Sodium biphosphate buffer was used as an equilibration buffer, sodium biphosphate containing $20 \mathrm{mM}$ imidazole as the also wash buffer and sodium biphosphate containing $500 \mathrm{mM}$ imidazole as the elution buffer. The protein was dialysed overnight following the elution and the concentration was determined by the Nanodrop A280 nm assay using the extinction coefficient 68215 $\mathrm{M}^{-1} \mathrm{~cm}^{-1}$ and molecular weight $51.8 \mathrm{kDa}$.

Purified recombinant TciMS was obtained under the same conditions as described above, except the wash and elution buffers also contained $8 \mathrm{M}$ urea. The recombinant $T c i$ MS was purified as inclusion bodies, therefore, refolded by dialysing in the buffer containing $8 \mathrm{M}, 6 \mathrm{M}, 4 \mathrm{M}, 2 \mathrm{M}$ or no urea for $12 \mathrm{~h}$ in each buffer at $4{ }^{\circ} \mathrm{C}$. The protein concentration was determined by the Nanodrop A280 nm assay using the extinction coefficient $66155 \mathrm{M}^{-1} \mathrm{~cm}^{-1}$ and molecular weight $62.5 \mathrm{kDa}$.

\subsection{Gel electrophoresis}

SDS-PAGE was performed using NuPAGE Novex 4-12\% Bis-Tris gels according to the instructions of the manufacturer (Invitrogen). Gels were stained with SimplyBlue ${ }^{\mathrm{TM}}$ SafeStain (Invitrogen). A western blot was also performed on the protein 
using a monoclonal anti-poly histidine-peroxidase antibody. Blots were incubated

overnight in 1:2000 antibody in buffer (4\% skim milk powder in Tris-buffered saline and $0.1 \%$ Tween-20) at room temperature and developed to detect His-tagged recombinant protein.

\subsection{TcilCL activity (E.C. 4.1.3.1)}

TciICL enzyme activity was measured at $30{ }^{\circ} \mathrm{C}$ in a coupled assay in which isocitrate was converted to glyoxylate, which combined with phenyldrazine. The increase in absorption was measured spectrophotometrically at $324 \mathrm{~nm}$. The final reaction mixture $(1 \mathrm{ml})$ contained $50 \mathrm{mM}$ imidazole assay buffer, $10 \mathrm{mM} \mathrm{MgCl} 2,1 \mathrm{mM}$ EDTA, $1 \mathrm{mM}$ isocitrate and $50 \mu \mathrm{g}$ recombinant protein.

(1) The optimum $\mathrm{pH}$ was determined with a substrate concentration of $1 \mathrm{mM}$ isocitrate and a $\mathrm{pH}$ range of 6 to 9. Subsequent assays were carried out at $\mathrm{pH} 7.5$.

(2) The apparent $\mathrm{K}_{\mathrm{m}}$ for isocitrate was determined in reaction mixtures containing 0$5 \mathrm{mM}$ of substrate. Subsequent assays were carried out at $1 \mathrm{mM}$ isocitrate.

(3) The effects of bivalent metal ions and potential inhibitors on recombinant TciICL activity was tested with $10 \mathrm{mM} \mathrm{Mg}{ }^{2+}, \mathrm{Mn}^{2+}, \mathrm{Cu}^{2+}, \mathrm{Ca}^{2+}, \mathrm{Zn}^{2+}$ and $\mathrm{Ni}^{2+}$ as chlorides, or $1 \mathrm{mM}$ malonate, tartronate or tartrate.

\subsection{Host recognition}

Pooled serum and saliva samples taken from parasite-naive and parasiteexposed sheep were tested for the presence of antibodies that react with recombinant TciICL by ELISA, using standard procedures. Serum and saliva samples were collected from 18 male 6-7 months-old Romney lambs previously exposed to multiple species of parasite, including T. circumcincta, to which they had developed immunity. $100 \mu$ per 
well of the $5 \mu \mathrm{g} / \mathrm{ml}$ TciICL was immobilised onto ELISA plates (Maxisorp, Thermofisher Scientific), free binding sites were blocked with Superblock (Thermo Scientific), followed by incubation with serial dilutions of serum (200- to 12800 -fold) or saliva (20to 320 -fold) in ELISA buffer for $2 \mathrm{~h}$ at room temperature. Bound serum immunoglobulins were detected by incubation for $2 \mathrm{~h}$ at $37^{\circ} \mathrm{C}$ with 1:4000 diluted rabbit anti-sheep IgGHRP and colour development with 3,3',5,5'-tetramethylbenzidine (TMB). Salivary IgA was similarly detected with rabbit anti-sheep IgA-HRP.

\subsection{Data analysis}

Replicate data are presented as mean $\pm \mathrm{SEM}, \mathrm{n}=3$. Graph Prism v5 was used to plot and analyse the kinetic data and estimate $\mathrm{K}_{\mathrm{m}}$ and $\mathrm{V}_{\max }$, using the non-linear fit function. The effects of metal ions and potential inhibitors was assessed using one-way ANOVA.

\section{Results}

\subsection{TcilCL and TciMS gene sequences}

The $1332 \mathrm{bp}$ full length $T$. circumcincta cDNA ICL and the $1575 \mathrm{bp}$ full length MS sequences, amplified from adult $T$. circumcincta cDNA, have been deposited in Genbank as Accession No SB7883248 and SB3620665 respectively. The nucleotide sequences were translated to amino acid sequence using Geneious Prime. The predicted proteins for TciICL and TciMS consisted of 444 and 525 amino acids respectively. Although Tci ICL and TciMS were cloned, expressed and purified as two separate proteins, the protein sequences from both of the proteins were joined for alignment and homology studies and comparing the substrate binding and active sites. 
Multiple alignments of the amino acid sequence of TciICL-MS showed high

\% identity with nematode homologues in Ancylostoma ceylanicum (GI: ABO31935), Ancylostoma caninum (GI: ABU68338), Haemonchus placei (GI: VDO27591.1), H. contortus (GI: CDL95172.1), Necator americanus (GI: XP_013301212.1), C. elegans

(GI: NP_001256387.1), Dictyocaulus viviparus (GI: KJH51538.1), Caenorhabditis briggsae (GI: CAP39673.2), S. stercoralis (GI: AAF00535.1) and Toxocara canis (GI: KHN81706.1). A. ceylanicum, H. contortus and H. placei ICL-MS were most closely related (90-92\%), while T. canis ICL-MS showed least identity (71\%). All active and binding sites are marked and completely conserved in TciICL-MS (Fig.1).

\subsection{TciICL and TciMS Structures}

The predicted 3D structures of TciICL and TciMS were modelled using the ITASSER server to identify the active sites and structural characteristics (Fig. 2). From the best five models obtained for TciICL, the selected model had a C-score of 0.57 , a TM value of $0.79 \pm 0.09$, a RMSD (root-mean-square deviation) of $5.8 \pm 3.7 \AA$, and normalized z-scores less than 9.14 (Fig. 2A). For TciMS, only one possible model was produced with a C-score of 1.97, a TM value of $0.99 \pm 0.04$, a RMSD of $3.4 \pm 2.4 \AA$, with normalized z-scores less than 8.96 (Fig. 2B).

The 3-dimensional structures, binding and catalytic sites have been determined for $T c i \mathrm{ICL}$ and $T c i \mathrm{MS}$ over a wide range of ligands and shown to be highly conserved (Fig. 2). The protein structures for the TciICL and TciMS superimposed best structural models corresponded to the monomers of $\underline{3 \mathrm{P} 0 \mathrm{X}}$ [28] and $\underline{3 \mathrm{~S} 9 \mathrm{Z}}$ [29], associated with the ICL and MS from Brucella abortus strain 2308 and Mycobacterium tuberculosis strain H37Rv (ATCC 25618), respectively. The \% identity of these sequences with the corresponding T. circumcincta sequences were $69 \%$ and $70 \%$. The Tci ICL ligand binding 
site (Ser-88, Gly-89, Trp-90, Asp-152, Cys-190, Gly-191, His-192, Arg-227, Glu-288, Asn-316, Ser-318, Ser-320, Thr-350, Leu-351) and the active site (His-179 and Arg-227)

residues that fall within $4 \AA$ of the substrate are shown in Fig. $2 B, C$. The catalytic residues of TciMS that fall within $4 \AA$ of the substrate correspond to Thr-87, Arg-159, Glu-243, Gly-268, Arg-269, Arg-270, Asp-271, Met-323, Trp-359, Met-437, Asp-439, Ala-441, and the active site residues to Asp-109, Glu-111, and Arg-159 (Fig. 2E, F). The 3D-structures of Tci ICL and TciMS revealed an overall structural homology with the enzymes of other nematode species.

\subsection{Recombinant protein expression}

Maximal production of functional recombinant ICL was obtained in the E. coli strain BL21 (DE3), when expression was induced with $0.2 \%$ L-arabinose for $16 \mathrm{~h}$ at 37 ${ }^{\circ} \mathrm{C}$. The purified N-terminal PolyHistidine recombinant TciICL protein appeared as a single band of about $52 \mathrm{kDa}$ on SDS-PAGE (Fig. 3). The presence of a His-tagged recombinant protein was confirmed by Western blotting (Fig. 3). Recombinant TciMS was expressed as inclusion bodies and attempts to solubilise the inclusion bodies with urea were unsuccessful. When the protein was dialysed in decreasing urea concentrations to facilitate the folding, the recombinant TciMS precipitated at $1 \mathrm{M}$ urea.

\subsection{Enzyme assays}

The optimum $\mathrm{pH}$ for recombinant TciICL activity at $30{ }^{\circ} \mathrm{C}$ was 7.5 (Fig. 4). The apparent $K_{m}$ for isocitrate was $0.7 \pm 0.01 \mu \mathrm{M}$ and the $V_{\max }$ was 275 nmoles $\min ^{-1} \mathrm{mg}^{-1}$ protein (mean \pm SEM, n=3) (Fig. 5). The Hill Coefficient was calculated to be 1.55 for the one site binding hyperbola, which was the preferred fit over other models. The effects of metal ions and inhibitors on recombinant enzyme activity are shown in Fig. 6. Enzyme 
activity was reduced by $60-90 \%$ when $\mathrm{Mg}^{2+}$ was replaced by the other bivalent ions and addition of $1 \mathrm{mM}$ malonate, tartrate or tartronate inhibited the activity by $60-80 \%$ (Fig. 6). TciMS assays were not carried out as the recombinant protein precipitated without urea.

\subsection{Host recognition}

Recombinant $T c i$ ICL was recognised in an ELISA by antibodies in both pooled serum and saliva collected from sheep exposed to nematodes in the field, but not from parasite-naïve animals (Fig. 7).

\section{Discussion}

The $T$. circumcincta GC enzymes ICL and MS were sequenced separately, as typically the two nematode enzymes form a bifunctional protein, too large to be expressed in E. coli. The probability of successfully expressing a soluble protein decreases considerably at molecular weights above $\sim 60 \mathrm{kDa}[30]$. Proteins that do not express in soluble form may not be modified or folded properly or may precipitate within E. coli through the formation of inclusion bodies. Whereas the ICL protein was expressed and confirmed to be an active enzyme which was recognised in an ELISA by antibodies in serum and saliva of sheep exposed in the field to mixed nematode infections, MS was expressed as inclusion bodies and was unable to be obtained in solution in urea concentrations compatible with carrying out confirmatory biochemical assays.

Although the proteins were expressed separately, protein alignments were carried out on the combined ICL-MS sequence. A 1332 bp full length cDNA sequence encoding $T$. circumcincta TciICL was amplified from adult $T$. circumcincta cDNA, cloned and expressed in E. coli. The 444 amino acid TciICL protein expressed in E. coli 
was functionally typical of isocitrate lyase of many species. A 1575 bp full length cDNA sequence encoding T. circumcincta TciMS was amplified, cloned and expressed in $E$. coli. The protein consists of 525 amino acids. The TciICL-MS protein sequence had 71$92 \%$ similarity to the enzyme homologues of other nematodes (Fig. 1), with all the tetramer interface and metal ion binding sites conserved.

The kinetic properties of the recombinant Tci ICL were generally similar to those of enzymes of other species. The optimum $\mathrm{pH}$ for $T c i \mathrm{ICL}$ activity at $30^{\circ} \mathrm{C}$ was $\mathrm{pH} 7.5$ (Fig. 5), similar to that for the ICL of H. contortus [9] and A. lumbricoides [7]. The enzyme activity at $30{ }^{\circ} \mathrm{C}\left(\mathrm{V}_{\max } 275 \pm 23\right.$ nmoles.min ${ }^{-1} \cdot \mathrm{mg}$ protein $\left.{ }^{-1}\right)$, was much higher than that reported for C. elegans [18], possibly because tissue extracts were used rather than a recombinant protein. The $\mathrm{K}_{\mathrm{m}}$ of $T c i \mathrm{ICL}$ for the substrate isocitrate was $0.7 \pm$ $0.01 \mu \mathrm{M}$ (Fig. 5), higher than the $0.25 \mu \mathrm{M}$ reported for recombinant $A$. lumbricoides ICL [7]. TciICL enzymatic activity was unchanged by the addition of $10 \mathrm{mM} \mathrm{Mg}^{2+}$, indicating that the enzyme is dependent on the bivalent metal ion for its activity. However, the enzyme activity decreased dramatically when $\mathrm{Mg}^{2+}$ was replaced by other metal ion (Fig. 6). Addition of $1 \mathrm{mM}$ inhibitor significantly inhibited recombinant TciICL activity (Fig. 6) as was the case for the free living nematode Turbatrix aceti [5, 31].

The recombinant TciMS protein was expressed in E. coli as inclusion bodies, which lack biological activity [32-34], but are often solubilised in high concentrations of chaotropic agents, such as urea [35]. Proteins expressed in inclusion bodies may not be folded correctly and be functional enzymes [36-38] as it depends on a number of factors such as $\mathrm{pH}$, ionic strength, temperature or the presence of various solvent additives. TciMS was solubilised with $8 \mathrm{M}$ urea, but precipitated in the buffer during subsequent dialysis at urea concentrations below $1 \mathrm{M}$. No confirmatory enzyme assays were 
therefore performed. It is not surprising why TciICL was expressed as a soluble protein whereas $T c i \mathrm{MS}$ was not as there are a number of factors that make one protein soluble and not the other. It depends on whether the protein is membrane bound, which is the case for MS [39] and also on the size of the protein [30]. Further experiments are needed to optimise the expression including trying a E. coli cell- free system.

Recombinant $T$. circumcincta ICL was antigenic and antibodies in both serum and saliva from field-immune, but not nematode-naïve, sheep recognised TciICL in an ELISA (Fig. 7). These sheep had been exposed to a number of nematode parasites including $T$. circumcincta and to have developed immunity to this very common parasite in New Zealand. The lack of a functional GC in the mammalian host further supports exploring its possible use for biological control of nematode parasites.

\section{Acknowledgments}

The authors would like to thank Drs Sandeep Gupta and Sofia Khanum for critically reviewing the manuscript. The financial support of AGMARDT (Grant No. P14003) is gratefully acknowledged.

\section{References}

[1] H.L. Kornberg, H.A. Krebs, Synthesis of cell constituents from C2-units by a modified tricarboxylic acid cycle, Nature 179 (1957) 988-991,

[2] M. Cioni, P.V. Pinzauti, P. Vanni, Comparative biochemistry of the glyoxylate cycle, Comp. Biochem. Physiol. B 70 (1981) 1-26,

[3] V.N. Popov, E.A. Moskalev, M.U. Shevchenko, A.T. Epeintsev, Comparative analysis of glyoxylate cycle key enzyme isocitrate lyase from organisms of different systematic groups, J. Evol. Biochem. Physiol. 41 (2005) 631-639, 
[4] M. Rothstein, H. Mayoh, Nematode biochemistry. VII. Presence of isocitrate lyase in Panagrellus redivivus, Turbatrix aceti, and Rhabditis anomala, Com. Biochem. Physiol. 16 (1965) 361-365.

[5] M.P. McKinley, L.A. Field, R.N. Trelease, Multiple forms of isocitrate lyase in the matrix of Turbatrix aceti mitochondria, Arch. Biochem. Biophys. 197 (1979) 253263 ,

[6] F.R. Khan, B.A. McFadden, Embryogenesis and the glyoxylate cycle, FEBS Letters 115 (1980) 312-314,

[7] J. Barrett, C.W. Ward, D.F. Fairbairn, The glyoxylate cycle and the conversion of triglycerides to carbohydrates in developing eggs of Ascaris lumbricoides, Comp. Biochem. Physiol. B 35 (1970) 577-586,

[8] H. Rubin, R.N. Trelease, Subcellular localization of glyoxylate cycle enzymes in Ascaris suum larvae, J. Cell Biol. 70 (1976) 374-383,

[9] M.J. Carrington, D.P. Jasmer, B.A. McFadden, Activities of isocitrate lyase and malate synthase during the development of free-living stages of Haemonchus contortus (Nematoda), Proc. Helminthol. Soc. Wash. 54 (1987) 277-279,

[10] F. Liu, J.D. Thatcher, J.M. Barral, H.F. Epstein, Bifunctional glyoxylate cycle protein of Caenorhabditis elegans: a developmentally regulated protein of intestine and muscle, Develop. Biol. 169 (1995) 399-414,

[11] A.A. Siddiqui, C.S. Stanley, S.L. Berk, Cloning and expression of isocitrate lyase from human round worm Strongyloides stercoralis, Parasite 7 (2000) 233-236,

[12] C. A. Ash, H.J. Atkinson, Evidence for a temperature-dependent conversion of lipid reserves to carbohydrate in quiescent eggs of the nematode, Nematodirus battus. Comp. Biochem. Physiol. B 76 (1983) 603-610, 
[13] F. Liu, J.D. Thatcher, H.F. Epstein, Induction of glyoxylate cycle expression in Caenorhabditis elegans: a fasting response throughout larval development, Biochemistry 36 (1997) 255-260,

[14] K.A.C. Madin, S.H. Loomis, J.H. Crowe, Anhydrobiosis in nematodes: Control of carbon flow through the glyoxylate cycle, J. Exp. Zool. 234 (1985) 341-350,

[15] B.H. Adhikari, D.H. Wall, B.J. Adams, Effect of slow desiccation and freezing on gene transcription and stress survival of an Antarctic nematode, J. Exp. Biol. 213 (2010) 1803-1812,

[16] C. Erkut, V.P. Gade, S. Laxman, T.V. Kurzchalia, The glyoxylate shunt is essential for desiccation tolerance in Caenorhabditis elegans and budding yeast, Biochem. Chem. Biol. Cell Biol. eLife 5 (2016) e13614,

[17] I.T. Lourenço-Tessutti, J.D.A. Souza, D. Martins-de-Sa, A.A.B. Viana, R.M.D.G. Carneiro, R.C. Togawa, J. de Almeida-Engler, J.A.N. Batista, M.C.M. Silva, R.R. Fragoso, M.F. Grossi-de-Sa, Knock-down of heat-shock protein 90 and isocitrate lyase gene expression reduced root-knot nematode reproduction, Phytopathology 105 (2015) 628-637,

[18] V.B. O'Riordan, A.M. Burnell, Intermediary metabolism in the dauer larva of the nematode Caenorhabditis elegans-II. The glyoxylate cycle and fatty-acid oxidation, Comp. Biochem. Physiol. B 95 (1990) 125-130,

[19] M.P. McKinley, R.N. Trelease, Regulation of carbon flow through the glyoxylate and tricarboxylic acid cycles in the mitochondria of Turbatrix aceti - I. Coarse and fine controls, Comp. Biochem. Physiol. B 67 (1980) 17-26,

[20] W.J. Colonna, B.A. McFadden, Isocitrate lyase from parasitic and free-living nematodes, Arch. Biochem. Biophy. 170 (1975) 608-619, 
[21] S. Umair, C. Ria, J.S. Knight, H.V. Simpson, Sarcosine metabolism in Haemonchus contortus and Teladorsagia circumcincta, Exp. Parasitol. 134 (2013) 1-6.

[22] J.S. Knight, A.H. Broadwell, W.N. Grant, C.B. Shoemaker, A strategy for shuffling numerous Bacillus thuringiensis crystal protein domains, J. Econ. Entomol. 9 (2004) 1805-1813,

[23] S.F. Altschul, T.L. Madden, A.A. Schäffer, J. Zhang, Z. Zhang, W. Miller, D.J. Lipman, Gapped BLAST and PSI-BLAST: a new generation of protein database search programs, Nucleic Acids Res. 25 (1997) 3389-3402,

[24] J. Yang, R. Yaan, A. Roy, D. Xu, J. Poisson, Y. Zhang, The I-TASSER Suite: Protein structure and function prediction, Nat. Methods 12 (2015) 7-8,

[25] R.A. Laskowski, J.A.C. Rullmann, M.W. MacArthur, R. Kaptein, J.M. Thornton, AQUA and PROCHECK-NMR: programs for checking the quality of protein structures solved by NMR, J. Biomol. NMR 8 (1996) 477-486,

[26] M. Wiederstein, M.J. Sippl, ProSA-web: interactive web service for the recognition of errors in three-dimensional structures of proteins, Nucleic Acids Res. 35 (2007) W407-W410,

[27] Y. Zhang, J. Skolnick, Scoring function for automated assessment of protein structure template quality, Proteins 57 (2004) 702-710.

[28] R.P. Bhusal, W. Jiao, B.X.C. Kwai, Acetyl-CoA-mediated activation of Mycobacterium tuberculosis isocitrate lyase 2, Nat. Commun. 10 (2019) 4639,

[29] I.V. Krieger, J.S. Freundlich, V.B. Gawandi, J.P. Roberts, V.B. Gawandi, Q. Sun, T.R. Ioerger, Structure-guided discovery of phenyl-diketo acids as potent inhibitors of Mycobacterium tuberculosis malate synthase, Chem. Biol. 19 (2012) 1556-1567,

[30] S. Gräslund, P. Nordlund, J. Weigelt, B.M. Hallberg, J. Bray, O. Gileadi, S. Knapp, Protein production and purification, Nat. Method. 5 (2018) 135-146, 
433 [31] U. Reiss, M. Rothstein, Isocitrate lyase from the free-living nematode Turbatrix aceti: Purification and properties, Biochemistry 9 (1974) 1796-1800. proteins, J. Biosci. Bioengineer. 4 (2005) 303-310,

[33] S. Ventura, A. Villaverde, Protein quality in bacterial inclusion bodies, Trend. Biotech. 24 (2006) 179-185,

[34] V. Upadhyay, A. Singh, D. Jha, A. Singh, A.K. Panda, Recovery of bioactive protein from bacterial inclusion bodies using trifluoroethanol as solubilization agent, Microb. Cell Fact. 15 (2016) 100,

[35] A. Mohammadain, H. Kaghazian, A. Kavianpour, R. Jalalired, Solubilization of inclusion body proteins using low and very low concentrations of chemicals: implications of novel combined chemical treatment designs in enhancement of postsolubilization target protein purity and biological activity, J. Chem. Tech. Biotech. 93 (2018) 1579-1587,

[36] N.K. Puri, E. Crivelli, M. Cardamone, R. Fiddes, J. Bertolini, B. Ninham, Solubilization of growth hormone and other recombinant proteins from Escherichia coli inclusion bodies by using a cationic surfactant, Biochemic. J. 285 (1992) 871879 ,

[37] R.R. Burgess, Purification of overproduced Escherichia coli RNA polymerase sigma factors by solubilizing inclusion bodies and refolding from Sarkosyl, Method. Enzymol. 273 (1996) 145-149,

[38] M. Kudou, D. Ejima, H. Sato, R. Yumioka, T. Arakawa, K. Tsumoto, Refolding single-chain antibody ( $\mathrm{scFv}$ ) using lauroyl-1-glutamate as a solubilization detergent and arginine as a refolding additive, Protein Express. Purif. 77 (2011) 68-74, 
[39] A.G. Kinhikar, D. Vargas, H. Li, S.B. Mahaffey, L. Hinds, J.T. Belisle, S. Laal, Mycobacterium tuberculosis malate synthase is a laminin- binding adhesin, Mol. Microbiol. 60 (2006) 999-1013,

\section{Figure Legends}

Fig. 1. Multiple protein sequence alignment of TciICL-MS, Ancylostoma ceylanicum ICL-MS (GI: ABO31935), Ancylostoma caninum ICL-MS (GI: ABU68338), Haemonchus placei ICL-MS (GI: VDO27591.1), Haemonchus contortus ICL-MS (GI: CDL95172.1), Necator americanus ICL-MS (GI: XP_013301212.1), Caenorhabditis elegans ICL-MS (GI: NP_001256387.1), Dictyocaulus viviparus ICL-MS (GI: KJH51538.1), Caenorhabditis briggsae ICL-MS (GI: CAP39673.2), Strongyloides stercoralis ICL-MS (GI: AAF00535.1) and Toxocara canis ICL-MS (GI: KHN81706.1). Active and ligand binding sites are marked by $\Delta$. The amino acid residues in grey represent ICL and the rest MS. The \% homology of each sequence with TciICL-MS is shown at the end of the alignment.

Fig. 2. The predicted tertiary structures of the Tci ICL (left) and TciMS (right) monomers. Locations are shown of the $\mathrm{C}$ - and $\mathrm{N}$-terminus in the predicted tertiary structure of TciICL (A) and TciMS (D). Superposition of the predicted tertiary structures showing the location of the active sites (mesh) within TciICL (B) and TciMS (E). The active sites of Tci ICL are shown in green (C) and TciMS in salmon (F) within $4 \AA$ of the superimposed 3P0X and 3S9Z active sites (mesh), respectively.

Fig. 3. A: Purified recombinant Tci ICL on a NuPage ${ }^{\mathrm{TM}} 4-12 \%$ Bis-Tris protein gel stained with SimplyBlue safe stain. Lane 1: Seeblue ${ }^{\mathrm{TM}}$ plus2 pre-stained protein standard 
in $\mathrm{kDa}$; Lane 2: filtered soluble bacterial lysate; Lane 3: unbound material; Lane 4: elution fraction ( $1 \mu \mathrm{g}$ of purified recombinant $T c i \mathrm{ICL}$ indicated by the black arrow). B: Western blot of recombinant purified TciICL. Lane 1: Seeblue ${ }^{\mathrm{TM}}$ plus2 pre-stained protein standard in $\mathrm{kDa}$; Lane $2: 1 \mu \mathrm{g}$ of recombinant TciICL detected by a monoclonal anti-polyhistidine-peroxidase antibody. C: Purified recombinant TciMS on a NuPage ${ }^{\mathrm{TM}}$ $4-12 \%$ Bis-Tris protein gel stained with SimplyBlue safe stain. Lane 1: Seeblue ${ }^{\mathrm{TM}}$ plus2 pre-stained protein standard in $\mathrm{kDa}$; Lane 2: non-induced fraction; Lane 3: induced fraction; Lane 4: filtered soluble bacterial lysate; Lane 5: solubilised inclusion bodies; Lane 6: elution fraction pre-refolding of purified recombinant TciMS; Lane 7: purified recombinant TciMS. D: Western blot of recombinant purified TciMS. Lane 1: Seeblue ${ }^{\mathrm{TM}}$ plus2 pre-stained protein standard in $\mathrm{kDa}$; Lane 2: $1 \mu \mathrm{g}$ of recombinant TciMS detected by a monoclonal anti-polyhistidine-peroxidase antibody.

Fig. 4. Effects of $\mathrm{pH}$ on the activity of recombinant $T c i \mathrm{ICL}$ at $30{ }^{\circ} \mathrm{C}$ (mean $\pm \mathrm{SEM}, \mathrm{n}=$ 3). Enzyme activity was measured in a coupled assay in which isocitrate was converted to glyoxylate, which combined with phenyldrazine; the increase in absorption was measured spectrophotometrically at $324 \mathrm{~nm}$.

Fig. 5. Effects of varying the substrate concentration on the activity of recombinant Tci ICL at $30^{\circ} \mathrm{C}($ mean \pm SEM, $\mathrm{n}=3)$. Enzyme activity was measured in a coupled assay in which isocitrate was converted to glyoxylate, which combined with phenyldrazine; the increase in absorption was measured spectrophotometrically at $324 \mathrm{~nm}$.

Fig. 6. The effects of bivalent metal ions and potential inhibitors on recombinant TciICL activity (relative activity, mean $\pm \mathrm{SEM}, \mathrm{n}=3$ ) at $30^{\circ} \mathrm{C}$. Enzyme activity was measured in a coupled assay in which isocitrate was converted to glyoxylate, which combined with 

nm.

Fig. 7. Recognition of recombinant Tci ICL by serially diluted immune serum (IgG) (top) or saliva (IgA) (bottom) (घ), but not by parasite-naïve serum or saliva $(\bullet)$. 
TCICL-MS

A. ceylanicum ICL-MS A. caninum ICL-MS

H. placei ICL-MS

H. contortus ICL-MS

$N$. americanus ICL-MS

C. elegans ICL-MS

D. viviparus ICL-MS

C. briggsae ICL-MS

S. stercoralis ICL-MS

T. canis ICL-MS
|

----MAQAAKNWYQVVKAAPKGRFQGIKRDYQVEDVLKLRGSVEIEYTLATRGANKLWQ

-----MAQAAKNWYQVIKAAPKGRFQGIKRDYQVEDVLKLRGSVEIEYTLATRGANKLWQ ----MAQAAKNWYQVIKAAPKGRFQG IKRDYQVEDVLKLRGSVEIEYTLATRGANKLWQ -----MTQVAKNWYQVVKAAPKGRFQGI IRDYHVEDVLKLRGSVEIEYTLATRGANKLWQ -----MTQVAKNWYQVVKAAPKGRFQGI IRDYHVEDVLKLRGSVEIEYTLATRGANKLWQ -------------VIRAAPKGRFQGIKRDYQVEDVLKLRGS IEIEYTLASRGANKLWQ -----MS SAAKNFYQVVKSAPKGRFKGIKRDYTVEDVLKLRGS I DI DYTLATRGANKLWQ -----MSSAAKNFYQVVKSAPKGRFKGIKRDYTVEDVLKLRGS I DI DYTLATRGANKLWQ MTTPAAGAAAKNFYQVVKSAPKGRFKGIKRDYTVEDVLKLRGS I DI DYTLATRGANKLWQ -----MRLKASNFYHIVKNSPKGRWTGIKRNYEI KDVLKLRGS LNIEYTLANKTSNKLWH ----MSQQ IAKNFYS I IKSAPKGRFAGLKRNYEVEDVLKLRGS IEIEYTLATRGANKLWQ LLHTEPFVPALGAQTGNQAVQMVRAGLKAIYLSGWQVAADANTAGDMY PDQSLYPANSGP LLHTEPFVPALGAQTGNQAVQMVRAGLKAIYLSGWQVAADANTAGDMY P DQSLYPANS GP LLHTEPFVPALGAQTGNQAVQMVRAGLKAIYLSGWQVAADANTAGDMYPDQSLYPANSGP LLHTEPFVPALGAQTGNQAVQMVRAGLKAIYLSGWQVAADANTAGDMYPDQSLYPANSGP LLHTEPFVPALGAQTGNQAVQMVRAGLKAIYLSGWQVAADANAAGDMYPDQSLYPANSGP LLHTEPFVPALGAQTGNQAVQMVRAGLKA IYLSGWQVAADANSAGDMYPDQSLYPANSGP LLHTEPFVPALGAQTGNQAVQMVRAGLKAIYLSGWQVAADANSAGDMY P DQSLYPANSGP LLHTEPFVPALGAQTGNQAVQMVRAGLKAIYLSGWQVAADANSAGDMYPDQSLYPANSGP LIHTEPYVAALGAQTGNQAVQMI KAGLKA IYLSGWQVAADGNTAGDMYPDQSLYPSNSGP LLHTEPFIAALGAQTGNQAVQMVRAGLPA IYLSGWQVAADMNCAGEMYPDQSLYPANSGP

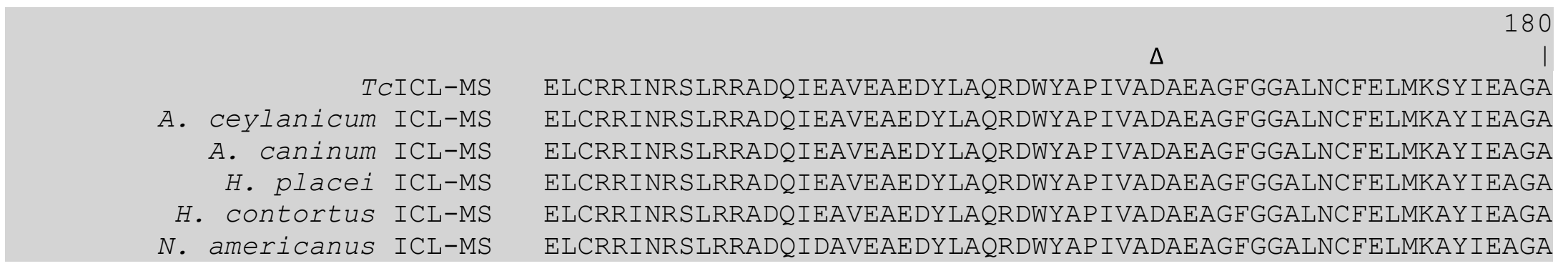


C. elegans ICL-MS

D. viviparus ICL-MS

C. briggsae ICL-MS

S. stercoralis ICL-MS

T. canis ICL-MS
ELAKRINRSLRRADQIEACEAEDYLAQRDWYAPIVADAEAGFGGALNCFELMKAYIEAGA ELAKRINRS LRRADQ IEACEAEDYLAQRDWYAP IVADAEAGFGGALNCFELMKAYIEAGA ELARRINRS LRRADQ IEACEAEDYLAQRDWYAP IVADAEAGFGGALNCFELMKAYIEAGA ELARRINKS LRRADQ IECAESDDMQPYRDYYAP IVADCEAGFGGSLNCFEITKSYIESGV ELCRRINKS LRRADQVEAVEAEDYRS SRDWYAP IVADAEAGFGGALNCFELMKAYIEAGA
TCICL-MS

A. ceylanicum ICL-MS A. caninum ICL-MS

H. placei ICL-MS

$H$. contortus ICL-MS

$N$. americanus ICL-MS

C. elegans ICL-MS

D. viviparus ICL-MS

C. briggsae ICL-MS

S. stercoralis ICL-MS T. canis ICL-MS
240

$\Delta$

$\Delta \Delta \Delta$

$\Delta$

作 AGVHFEDQLGSEKKCGHMGGKVL I PTAQH IRHLNAARLAADVCGAPT I IVARTDAESSRI SGVHFEDQLGSEKKCGHMGGKVLI PTAQH IRHLNAARLAADVCGAPTI IVARTDAESSRL AGVHFEDQLGSEKKCGHMGGKVLI PTAQH IRHLNAARLAADVCGAPTIVVARTDAESSRL AGVHFEDQLGSEKKCGHMGGKVLI PTAQH IRHLNAARLAADVCGAPT IVVARTDAESSRL AGVHFEDQLGSEKKCGHMGGKVLI PTAQH IRHLNAARLAADVCGTPTI IVARTDAESSRI AGVHYEDQLGSEKKCGHMGGKVLI PTAQH IRHLNASRLAADVCGVPTI IVARTDAESSRI AGVHYEDQLGSEKKCGHMGGKVLI PTAQH IRHLNASRLAADVCGVPTI IVARTDAESSRL AGVHYEDQLGSEKKCGHMGGKVLI PTAQH IRHLNASRLAADVCGVPTI IVARTDAESSRI AGVHFEDQLGSEKKCGHMGGKVLI PISEHIRHLNAARLAADVCDTPTI IVARTDAESARL AGVHYEDQLGSEKKCGHMGGKVLI PTEQH IRHLNAARLAADVCGVPTI IVARTDAESARL

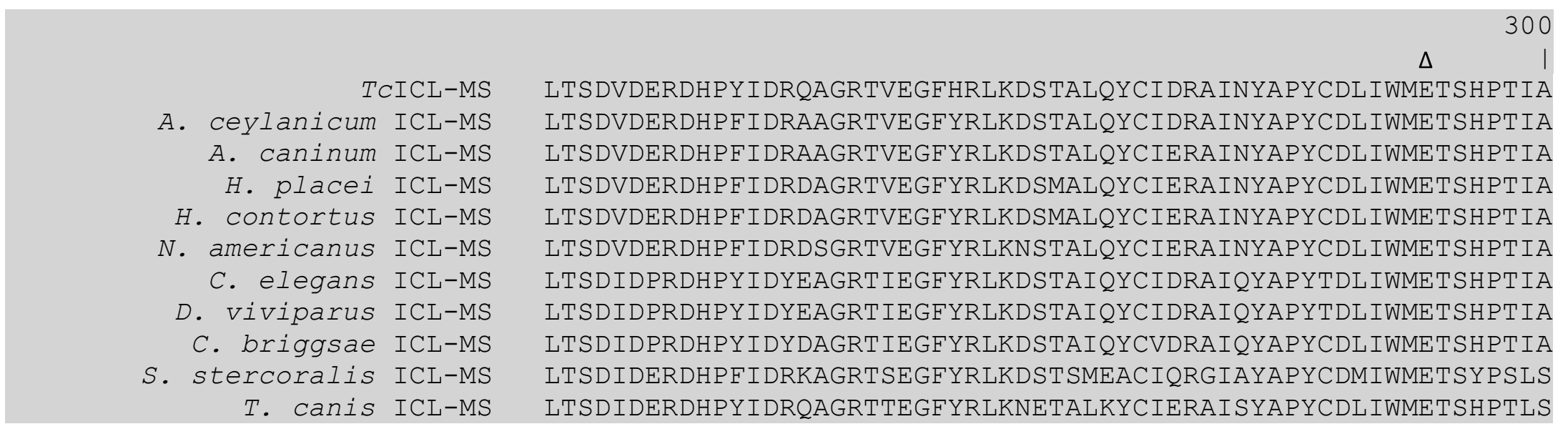


$\Delta \Delta \triangle \Delta \Delta \Delta$ $\Delta \Delta \quad$ ।

TCICL-MS

A. ceylanicum ICL-MS A. caninum ICL-MS

H. placei ICL-MS $H$. contortus ICL-MS

$N$. americanus ICL-MS C. elegans ICL-MS D. viviparus ICL-MS C. briggsae ICL-MS

S. stercoralis ICL-MS T. canis ICL-MS

DAREFAEGVRKVYPDKMFAYNCSPSFNWKOHLSPTOLEKFOKELGALGFKYOFITLAGFH DAREFAEGVRKVYPDKMFAYNCS P SFNWKKHLSPAQMEKFQKELGALGFKYQFITLAGFH DAREFSEGVRKVYPDKMFAYNCS PSFNWKKHLSPAQMEKFQKELGALGFKYQFITLAGFH DAREFAEGVRKVYPDKMFAYNCS PSFNWKKHLS SSQLEKFQKELGALGFKYQFITLAGFH DAREFAEGVRKVYPDKMFAYNCSPSFNWKKHLSSSQLEKFQKELGALGFKYQF ITLAGFH DAREFAEGVRKVY PDKMFAYNCS P SFNWKKHLSPAQMEKFQKELGALGFKYQFITLAGFH DAREFAEGVHKQYPDKMFAYNCS PSFNWKKHLSPSQMEKFQKELGAMGFKYQFITLAGYH DAREFAEGVHKQY PDKMFAYNCS PSFNWKKHLSPSQMEKFQKELGAMGFKYQFITLAGYH DAREFAEGVHKQY PDKMFAYNCS PSFNWKKHLSPSQMEKFQKELGAMGFKYQF ITLAGFH QAKEFAEGVKREFPDKLFAYNCS PSFNWGKHLKKSDMEKYQRELGAMGFKYQFITLAGYH DAKEFAEGVRKVYPDKLFAYNCS P SFNWRKHLRPVDLEKFQKELGAMGFKYQFITLAGFH

ANSYSMFDLARNYKEKGMLAYSSLQQQEFAAEQHGYSAVKHQREVGTGYFDHISNAVTGG ANSYSMFDLARNYKDKGMLAYSQLQEAEFESEKHGYSAVKHQREVGTGYFDHISNAVTGG ANSYSMFDLARNYKDKGMLAYSQLQEAEFEAEKHGYSAVKHQREVGTGYFDHISNAVTGG ANSFSMFDLARNYREKGMLAYSNLQEAEFAAEQHGYSAVKHQREVGTGYFDHISNAVTGG ANSFSMFDLARNYREKGMLAYSNLQEAEFAAEQHGYSAVKHQREVGTGYFDHISNAVTGG ANSFSMFDLARNYKDKGMLAYSQLQEAEFESEKYGYSAVKHQREVGTGYFDHISNAVSGG ANSYSMFDLARNYKEKGMLAYSGLQEGEFAAEKHGYTAVKHQREVGTGYFDAVSRAVTGG ANSYSMFDLARNYKEKGMLAYSGLQEGEFAAEKHGYTAVKHQREVGTGYFDAVSRAVTGG ANSYSMFDLAKNYKETGMLAYSALQEGEFAAEKHGYTAVKHQREVGTGYFDAVSRAVTGG TNSFS I FDLAKNYRERGMAAYAELQKAEFDAEKSGYTAVKHQREVGTGYFDVLGNACAGG CNSFSVYDLARKYRERGMAAYSELQENEFDSEKHGYSAVKHQREVGTGYFDHVANAITGG

480

TCICL-MS

A. ceylanicum ICL-MS A. caninum ICL-MS H. placei ICL-MS H. contortus ICL-MS N. americanus ICL-MS C. elegans ICL-MS
QSSTTALAGSTEEAQF--HT-ATAS-SEDEEIMTLTAPMAAGDEKILTPDALRFIKDLNK QSSTTALTGSTEEAQF--FT-ATAS-SEDEE IMTLTAPTLAGDEKILTPDALRFIKELNK QSSTTALTGSTEEAQF--FT-ATAS-SEDEEIMTLTAPTLAGDEKILTPDALRFIKDLNK MSSTTALTGSTEEAQF--KT-ITAS-SDDEEILVLTAPLNTGDEKILTPDALRF IKDLNL MSSTTALAGSTEEAQFKTIT----ASSDDEEILVLTAPLNTGDEKILTPDALRFIKDLNL QSSTTALSGSTEEAQF--FT-ATAS-SEDEEILTLTAPTLAGDEKILTPDALRF IKDLNK LSSTTALSGSTEEAQF--Q---TAVASQDEEILSLTAQNVAGDEKILTPDALRFLHDLNT 
D. viviparus ICL-MS

C. briggsae ICL-MS

S. stercoralis ICL-MS

T. canis ICL-MS
LSSTTALSGSTEEAQF--Q---TAVASQDEEILSLTAQNVAGDEKILTPDALRFLHDLNT LSSTTALSGSTEEAQF--QTA-VASASEDEEILSLTAQTVAGDEKILTPDALRFLHDLNT SSSTTALTGSTEEAQF--KT--TAV--EDDEVMTVSKNATV-----------------QASTVALSGSTEEAQFSDKPHTTTAPPDEDEILMMTAPEVSGDEKILTPNALRFLKELHQ
TCICL-MS

A. ceylanicum ICL-MS

A. caninum ICL-MS

H. placei ICL-MS

H. contortus ICL-MS

N. americanus ICL-MS

C. elegans ICL-MS

D. viviparus ICL-MS

C. briggsae ICL-MS

S. stercoralis ICL-MS

T. canis ICL-MS

TCICL-MS

A. ceylanicum ICL-MS

A. caninum ICL-MS

H. placei ICL-MS

H. contortus ICL-MS

$N$. americanus ICL-MS

C. elegans ICL-MS

D. viviparus ICL-MS

C. briggsae ICL-MS

S. stercoralis ICL-MS

T. canis ICL-MS

\section{TCICL-MS}

A. ceylanicum ICL-MS
540

$\Delta \mathrm{I}$

KFDGKRRELLKKRQQVQIEINDGVYFPDFSSETAHLREDMGWKGSEIPQDLQDRRVEITG KFDEKRRKLLKKRVVLQKDINEGAWFPDFASDTANIRDDMGWKGAEIPDDLQNRRVEITG KFEEKRRKLLKKRVVMQKD INEGAWFPDFASDTAQIRDDKGWKGAEIPEDLQNRRVEITG KFDGRRQELLKKRVQKQKEINDGVYFPDFSPDTANLREDLSWKGAEIPEDLMDRRVEITG KFDGRRQELLKKRVQKQKEINDGVYFPDFSPDTANLREDLSWKGAEIPEDLMDRRVEITG KFDDKRRKLLKKRTYLQKDINEGAWFPDFSPDTADIRNDKGWKGAEI PPDLQDRRVEITG EFNPRRLRLLSKRNQVQADINNS LWFPDFNKETEVLRS DQGWKGAEI PRDLQDRRVEITG EFNPRRLRLLSKRNQVQADINNS LWFPDFNKETEVLRS DQGWKGAE I PRDLQDRRVEITG EFNPRRLRLLSKRRQVQDDINSSLWFPDFNKETEVLRSDQGWKGAE I PRDLQDRRVEITG

KFDARRLQLLAQRKLVQVS IDDSNYFPDFDPATKGLREDHAWFGAKI PDDMLDRRVEITG

600

PTDRKMVINALNSGANVFMADFEDSNTPSWRNQLEGQVNLYDAVRDNISYMHPTTKKEYT PTDRKMI INALNS GANVFMADFEDSNTPSWRNQLDGQ I NLYDAVRNNI S YMHPTTKKEYT PTDRKMI INALNSGANVFMADFEDSNTPSWRNQLDGQINLYDAVRNNI SYVHPTTKKEYT PTDRKMI INALNS GANVFMADFEDSNTPSWRNQLDGQI NLYDAVRNNI SYEHPSTKKEYT PTDRKMI INALNSGANVFMADFEDSNTPSWRNQLDGQ INLYDAVRNNISYEHPSTKKEYT PTDRKMI INALNSGAS I FMADFEDSNTPSWRNQLDGQINLYDAVRNNI SYVHPSTKKEYS PTDRKMVINAMNSGANVFMADFEDSNSPTWRNQLEGQINLYDAVRNNI SYTHPTTKKEYT PTDRKMVINAMNSGANVFMADFEDSNSPTWRNQLEGQINLYDAVRNNISYTHPTTKKEYT PTDRKMVINAMNSGANVFMADFEDSNSPTWRNQLEGQINLYDAVRKNI SYVHPTTKKEYT

660 LNQKVAVL------------------------------------------------LNKETSVL---------------------------------------------------- 
A. caninum ICL-MS

H. placei ICL-MS

H. contortus ICL-MS

$N$. americanus ICL-MS

C. elegans ICL-MS

D. viviparus ICL-MS

C. briggsae ICL-MS

S. stercoralis ICL-MS

T. canis ICL-MS

TCICL-MS

A. ceylanicum ICL-MS

A. caninum ICL-MS

H. placei ICL-MS

H. contortus ICL-MS

$N$. americanus ICL-MS

C. elegans ICL-MS

D. viviparus ICL-MS

C. briggsae ICL-MS

S. stercoralis ICL-MS

T. canis ICL-MS

TCICL-MS

A. ceylanicum ICL-MS

A. caninum ICL-MS

H. placei ICL-MS

H. contortus ICL-MS

$N$. americanus ICL-MS

C. elegans ICL-MS

D. viviparus ICL-MS

C. briggsae ICL-MS

S. stercoralis ICL-MS

T. canis ICL-MS

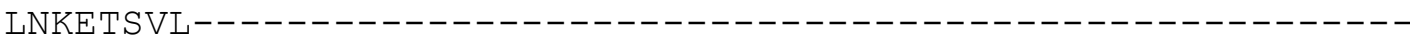

LDKKVSVL--------------------------------------------------

$\mathrm{LDKK}-----------------------------------------------------$

LNKQTSVL-------------------------------------------------

LNEKHAVL----------------------------------------------------

LNEKHAVL-------------------------------------------------

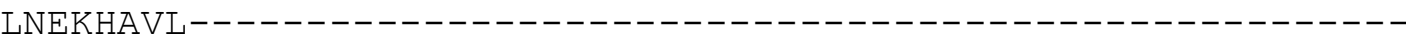

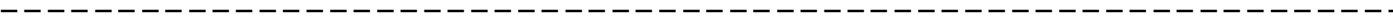

LKENHAGMTSPFLRAYTLSSIKVCHSRNIAAMGGMAAQIP IKHDQTANRKALALVRQDKE

720

$\Delta$

$--\mathrm{N}--\mathrm{V}---\mathrm{RPRGWHLPEKHVLIHNKPTSGSLFDFGLFVYHNAKALKDKGSGPYFYLPKI}$ K--V-----RPRGWHLPEKHVLI HNKPTSGS LFDFGLFVYHNARALMDKGSGPYFYLPKL -- - - - KVRPRGWHLPEKHVLI HNKPTSGS LFDFGLFVYHNARALMDKGSGPYFYLPKL K--V--R--RPRGWHLPEKHVLIHNKPTSGS LFDFGLFLFHNAKVLKDKGTGPYFYLPKL -- -VSVLKVRPRGWHLPEKHVLIHNKPTSGS LFDFGLFLFHNAKVLKDKGTGPYFYLPKL $------K V R P R G W H L P E K H V L I H N K A T S G S L F D F G L F I Y H N A K A L L D K G S G P Y F Y L P K I$ K- -V--R---PRGWHLPEKHVLI HNQPTSGS LFDFGLFVFHNAKALIAQGSGPYFYLPKL K--V--R---PRGWHLPEKHVLIHNQPTSGS LFDFGLFVFHNAKALIAQGSGPYFYLPKL -K--V----RPRGWHLPEKHVLI HNQPTSGS LFDFGLFVFHNAKALIAQGSGPYFYLPKL

REATDVLNVRPRGWHLPEKHVLVNGQPMSGALFDFGLFLFHNAKALLDKGSGPYFYLPKI

780

$\Delta$

$\triangle \Delta$

QNAEEAKLWAEVFAYSEDRLDLPRGT I KCTVLIEHLLATFQMNE I IYALKDH IVGLNCGR QSAEEAKLWAEVEQYTEERLDLPKGT IKCTVLIEHLLASFQMNE I IYALKDYIVGLNCGR QSAEEAKLWAEVFQYTEQQLNLPKGT IKCTVLIEHLLASFQMNE I IYELKDYIVGLNCGR QNAEEAQLWADVFDYAEHTLRLPQGT IKCTVLIEHLLASFQMNE I IYALKDY IVGLNCGR QNAEEAQLWADVFDYAEHTLRLPQGTIKCTVLIEHLLASFQMNE I IYALKDYIVGLNCGR QSAEEAKLWAEVFEYAEQRLELPKGT IKCTVLIEHLLASFQMNE I IYALKDYIVGLNCGR QSAEEAQLWADVFKYTEDKLGLARGTIKCTVLIEHLLASFQLHE I I HALKDNIVGLNCGR QSAEEAQLWADVFKYTEDKLGLARGTIKCTVLIEHLLASFQLHEIIHALKDNIVGLNCGR QSAEEAQLWADVFKYTEEKLGLARGT IKCTVLIEHLLASFQLHEI I HALKDNIVGLNCGR

QNAEEAKLWADVFAFAEQSVGIPRGS IKCTVLIEHLLATFQ-------------G----- 
TCICL-MS

A. ceylanicum ICL-MS A. caninum ICL-MS

H. placei ICL-MS

H. contortus ICL-MS

$N$. americanus ICL-MS

C. elegans ICL-MS

D. viviparus ICL-MS

C. briggsae ICL-MS

S. stercoralis ICL-MS

T. canis ICL-MS

TCICL-MS

A. ceylanicum ICL-MS

A. caninum ICL-MS

H. placei ICL-MS

H. contortus ICL-MS

$N$. americanus ICL-MS

C. elegans ICL-MS

D. viviparus ICL-MS

C. briggsae ICL-MS

S. stercoralis ICL-MS

T. canis ICL-MS

TCICL-MS

A. ceylanicum ICL-MS

A. caninum ICL-MS

H. placei ICL-MS

H. contortus ICL-MS

N. americanus ICL-MS

C. elegans ICL-MS

D. viviparus ICL-MS
$\Delta \Delta$

$\Delta$

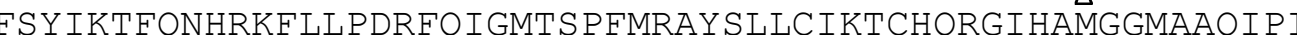
WDYI FSYIKTFQNHRKF LLPDRFQ I GMTS PFMRAYS LLC I KTCHQRG I HAMGGMAAQ I P I WDY I FSY I KTFQNHRKF LLPDRFQ I GMTS PFMRAYS LLCI KTCHQRG I HAMGGMAAQ I P I WDYIFSYIKTFQNHRKYLLPDRFQIGMTS PFMRAYS LLC I KTCHQRG I HAMGGMAAQI P I WDY I FSY IKTFQNHRKYLLPDRFQ I GMT S PFMRAYSLLC IKTCHQRG IHAMGGMAAQ I P I WDY I FSYIKTFQNHRRF LLPDRFQ I GMTS P FMRAYS LLCIKTCHLRG I HAMGGMAAQ I P I WDYIFSYIKTFQNHRKFLLPDRFQ I GMTAPFMRNYS LEVIKACHLRGI HAMGGMAAQ I P I WDYIFSYIKTFQNHRKF LLPDRFQ IGMTAPFMRNYS LEVIKACHLRGI HAMGGMAAQI P I WDYIFSYIKTFQS HRKF LLPDRFQ I GMTAPFMRNYS LEVIKACHQRGI HAMGGMAAQI P I

-----------------------MTSPFLRAYTLSS IKVCHSRNIAAMGGMAAQI P I

900

KNDD---------------V------ANSKALALVHQDKEREATDGHDGTWVAHPGLVPI

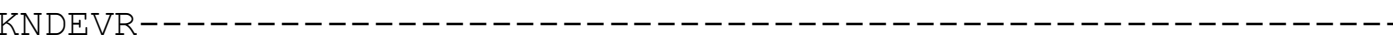
KNDERWQVCRYGNAI FYHMSREQCEVANSKALSLVRQDKEREATDGHDGTWVAHPGLVS I KNDE----V----------------ANSKALALVHQDKDREVIDGHDGTWVAHPGLVQI KND-------------------EVANSKALALVHQDKDREVIDGHDGTWVAHPGLVQI KNDE------V--------------ANGKALALVRQDKEREATDGHDGTWVAHPGLVHV KHDQ----V-----------------ANDKAFALVRADKEREATDGHDGTWVAHPGLVPI KHDQ----V----------------ANDKAFALVRADKEREATDGHDGTWVAHPGLVPI KHDP----A-----------------ANDKAFALVRADKEREVTDGHDGTWVAHPGLVPL KHDQT---------------------ANRKAIAIVRODKEREATDGHDGTWVAHPDIVSV

ARKVFDDCMPSANQIEKQLQSFFVTNQELTAI PEGTRTDHGFRHNISVTLGYLDSWLRGV ARQVFDECMPT PNQLHKQLESLLTTKEDLTAIPEGTRTEAGFRHNISVTLGYLDSWLRGV AKRIFDEHMPT PNQI DKQLQGFFATNQELTA I PEGTRTEHGFRHNISVTLGYLDSWLRGV AKRIFDEHMPTPNQINKQLQGFFATNQELTA I PEGTRTEHGFRHNISVTLGYLDSWLRGV ARQVFDAHMPSANQIQKQYENLVTTKEDLTA I PEGTRTENGFRHNISVTLGYLDSWLRGV AKRVFDQMMPKPNQISKNLTRANCTKEDLTVIPEGTRTEAGFRHNISVTLGYLDSWLRGT AKRVFDQMMPKPNQI SKNLTRANCTKEDLTVIPEGTRTEAGFRHNISVTLGYLDSWLRGT 
C. briggsae ICL-MS

S. stercoralis ICL-MS

T. canis ICL-MS
AKGVFDQMMPKPNQINKLLSRSPCSKEDLTVIPEGTRTEAGFRHNISVTLGYLDSWLRGT

AREVEDGLMPSKNOIEKRIDSESVTNADLTA PEGTRTERGFRHNISVTIGYMDSWIRGV
TCICL-MS

A. ceylanicum ICL-MS

A. caninum ICL-MS

H. placei ICL-MS

H. contortus ICL-MS

N. americanus ICL-MS

C. elegans ICL-MS

D. viviparus ICL-MS

C. briggsae ICL-MS

S. stercoralis ICL-MS

T. canis ICL-MS

TCICL-MS

A. ceylanicum ICL-MS

A. caninum ICL-MS

H. placei ICL-MS

H. contortus ICL-MS

$N$. americanus ICL-MS

C. elegans ICL-MS

D. viviparus ICL-MS

C. briggsae ICL-MS

S. stercoralis ICL-MS

T. canis ICL-MS
1020 GCVPLYNLMEDAATAEISRSQLWQWLRHDARLE--------------D-----GRTID

GCVPLYNLMEDAATAEISRAQLWQWLRHDARLE----------------D-G----RTVD GCVPLYNLMEDAATAEISRSQLWQWLRHDARLE----------------DG-----RTID GCVPLYNLMEDAATAE ISRSQLWQWLRHDARLE---------------------DGRTID GCVPLYNLMEDAATAEISRAQLWQWLRHDARLEGKFRKGRGQGCEWLGFDGGIPDGRTID GCVPLYNLMEDAATAEISRAQLWQWLHHDAKLE---------------DG-----RTID GCVPLYNLMEDAATAEI SRAQLWQWLHHDAKLE----------------DG-----RTID GCVPLYNLMEDAATAEISRAQLWQWLHHDAKLE---------------DG-----RTID

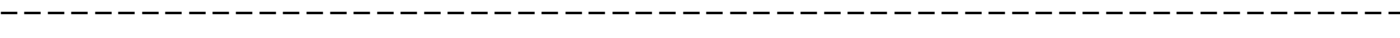

GCVPLYNLMEDAATAEISRAQLWQWLHHEAKLE----------------DG-----RTID

1021

AQLVKQTIAAETERRLIRAGSVVSRLPEAAELLEKFALEEHMSDFLTLDAYDKLVSEGH

AQLVKQTIAAETERRLIRAGSVVSRLPEAAELLEKFALEENMSDFLTLDAYDKLVSEGH AQLVKQTIAAETERRLIRAGSVVSRLPEAAELLEKFALEEQMSDFLTLDAYDKLVSEGH AQLVKQTIAAETERRLIRAGSVVSRLPEAAELLEKFALEEQMSDFLTLDAYDKLVSEGH AQLVKQTIAAETERRLIRAGS IVSRLPEAAELLEKFALEENMSDFLTLDAYDKLVSEGH AGLVKQTIAAETERRLIRAGSVVNRI PEAADLLEKFVTEEKMSDFLTTDAYDRLVSEGY AGLVKQTIAAETERRLIRAGSVVNRI PEAADLLEKFVTEEKMSDFLTTDAYDRLVSEGY AGLVKQTIAAESERRLIRAGSVVNRI PEAAELLEKFVTEEKLSDFLTTDAYDKLVSEGY ----------------------------------------------------------VEMVRQTIAAETERRMIRAGS IVNRLPEAAELLEKFATEPELSDFLTLDAYDRLVSEGK identity

[92\%]

[88\%]

[90\%]

[89\%]

[87\%]

[83\%]

[83\%]

[83\%]

[72\%]

[71\%] 
Figure 2

A
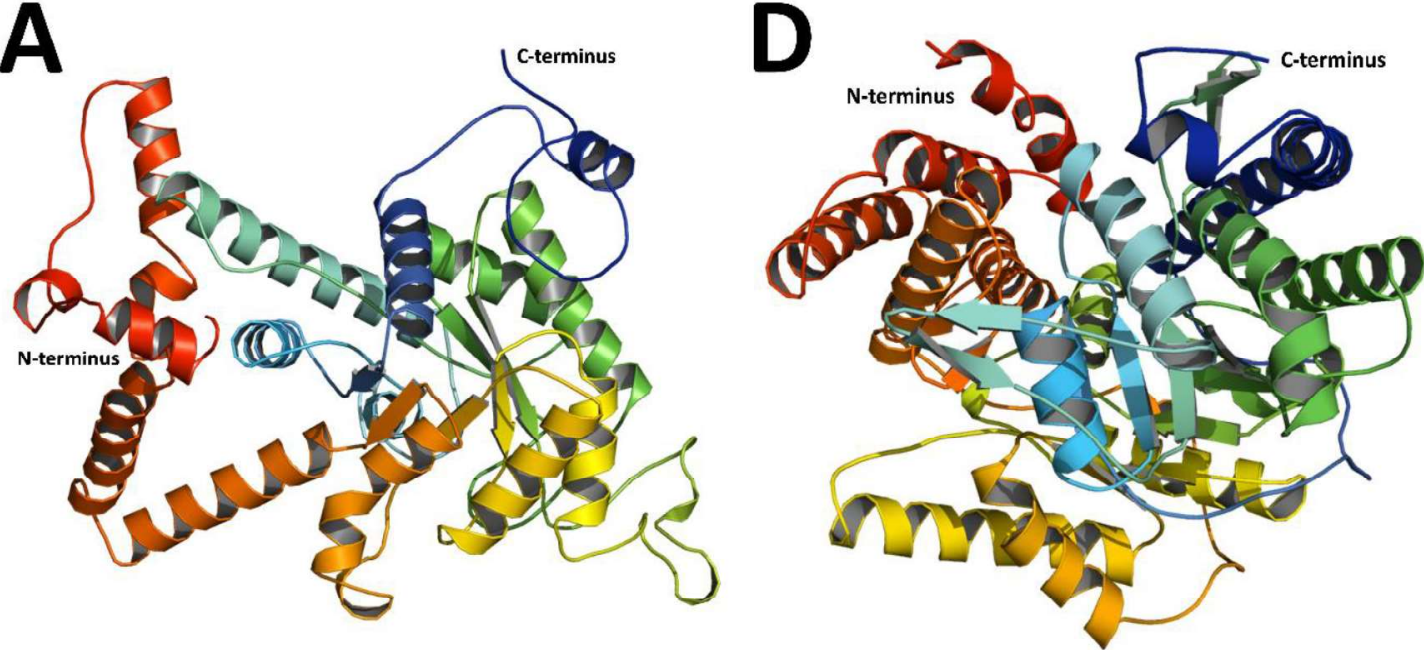

B

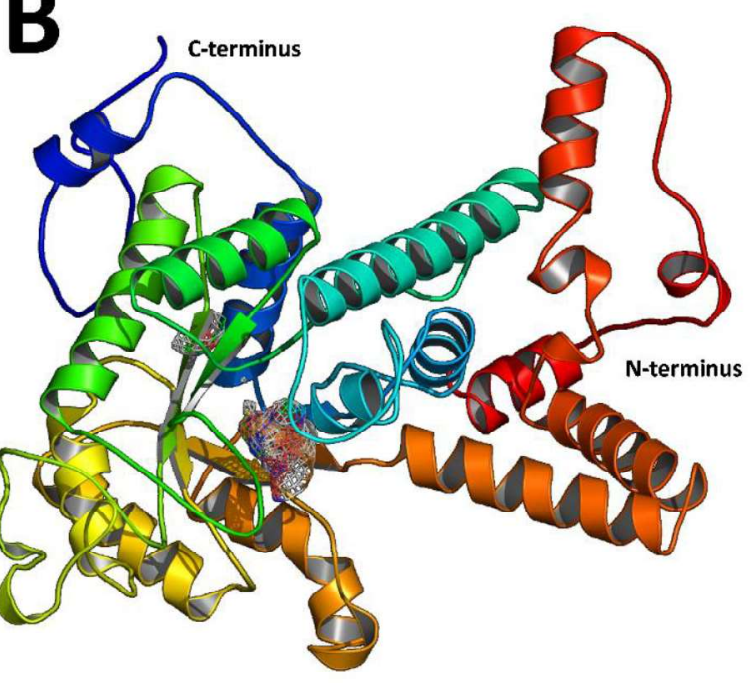

E

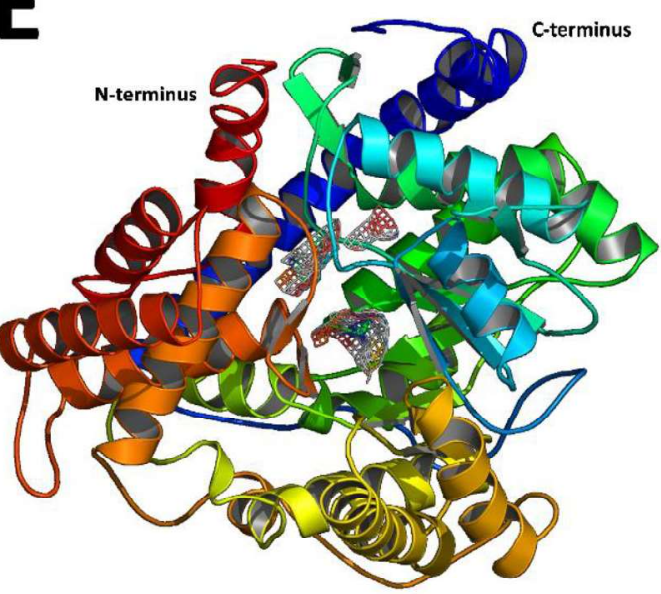

C

C

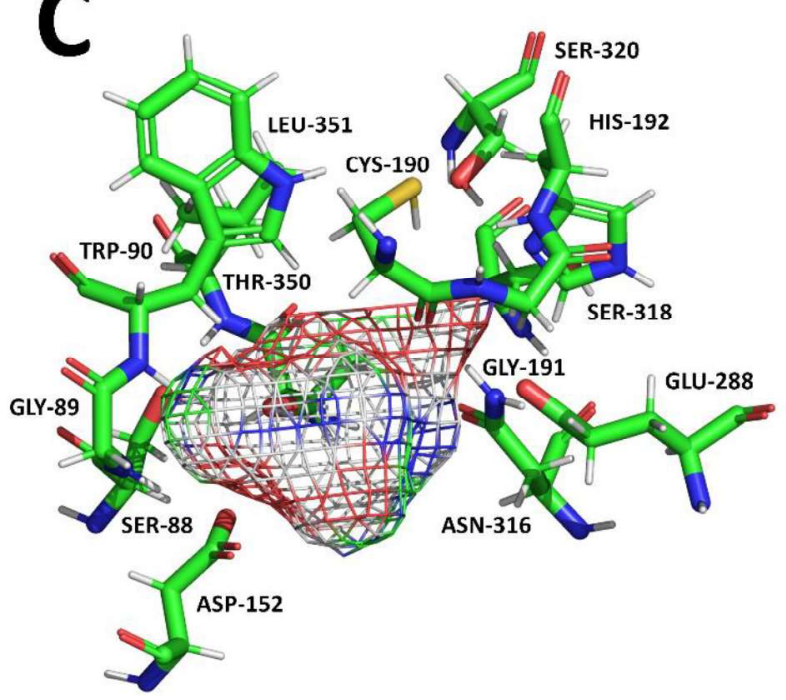

F

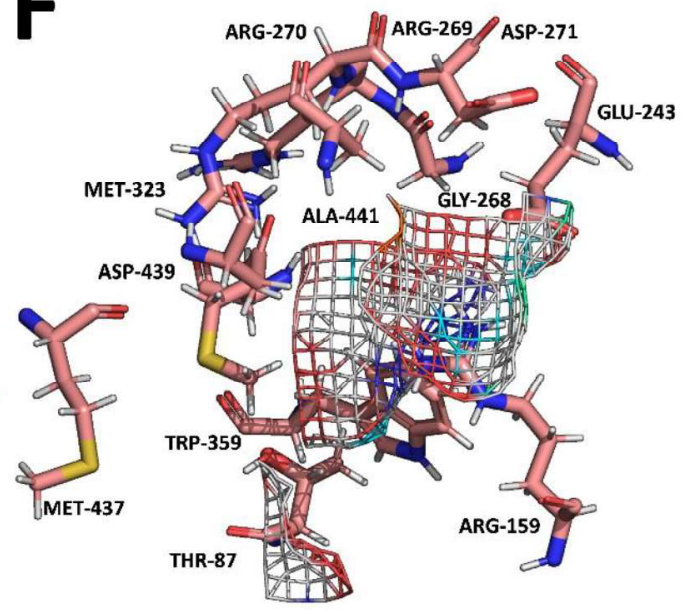




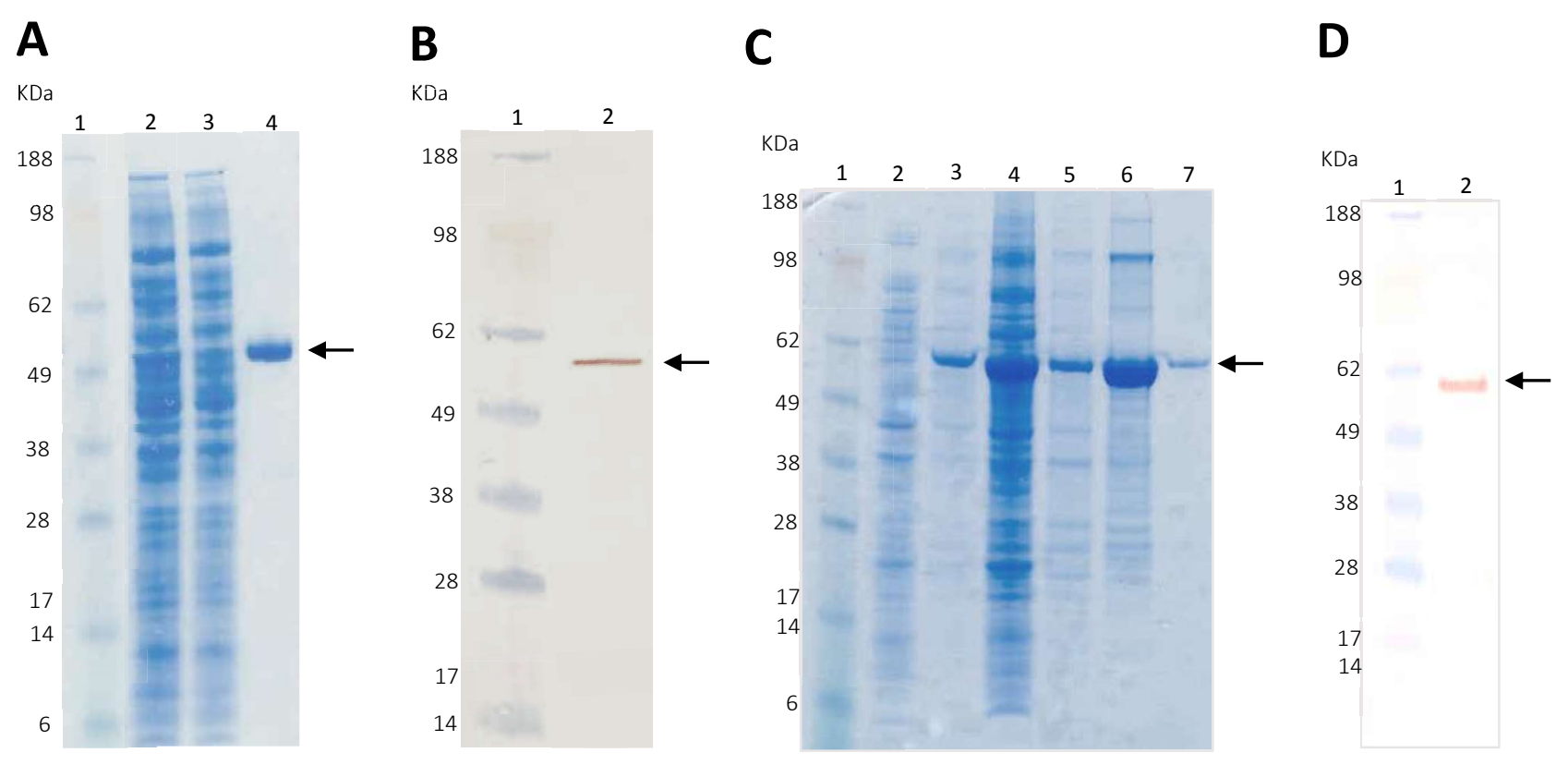


Figure 4

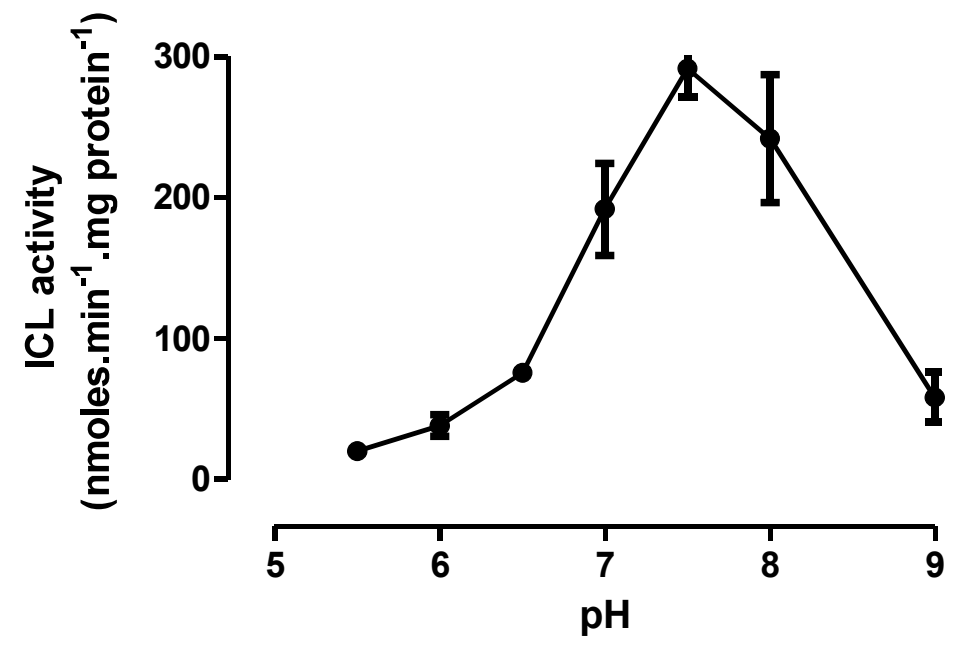




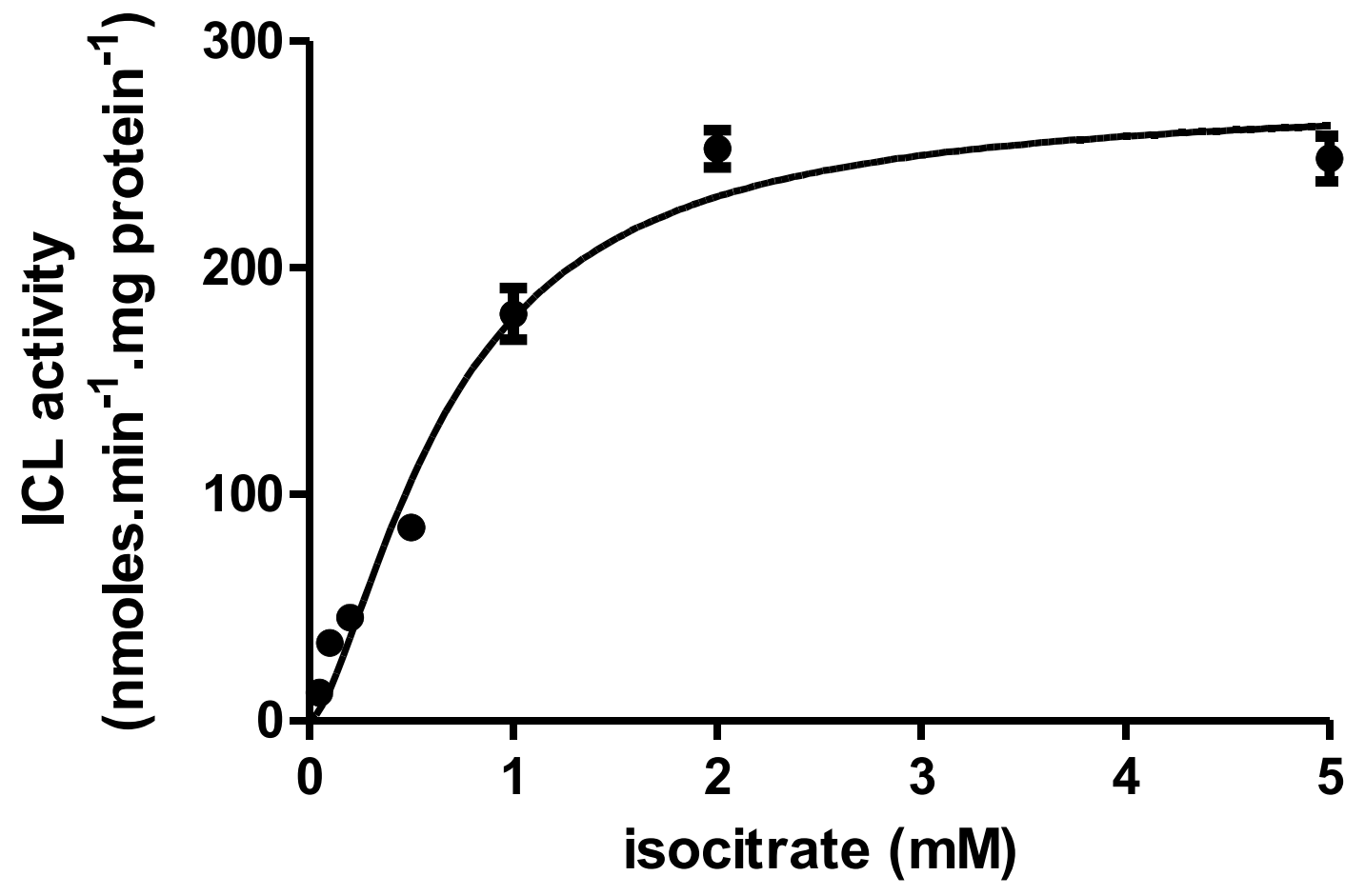


Figure 6
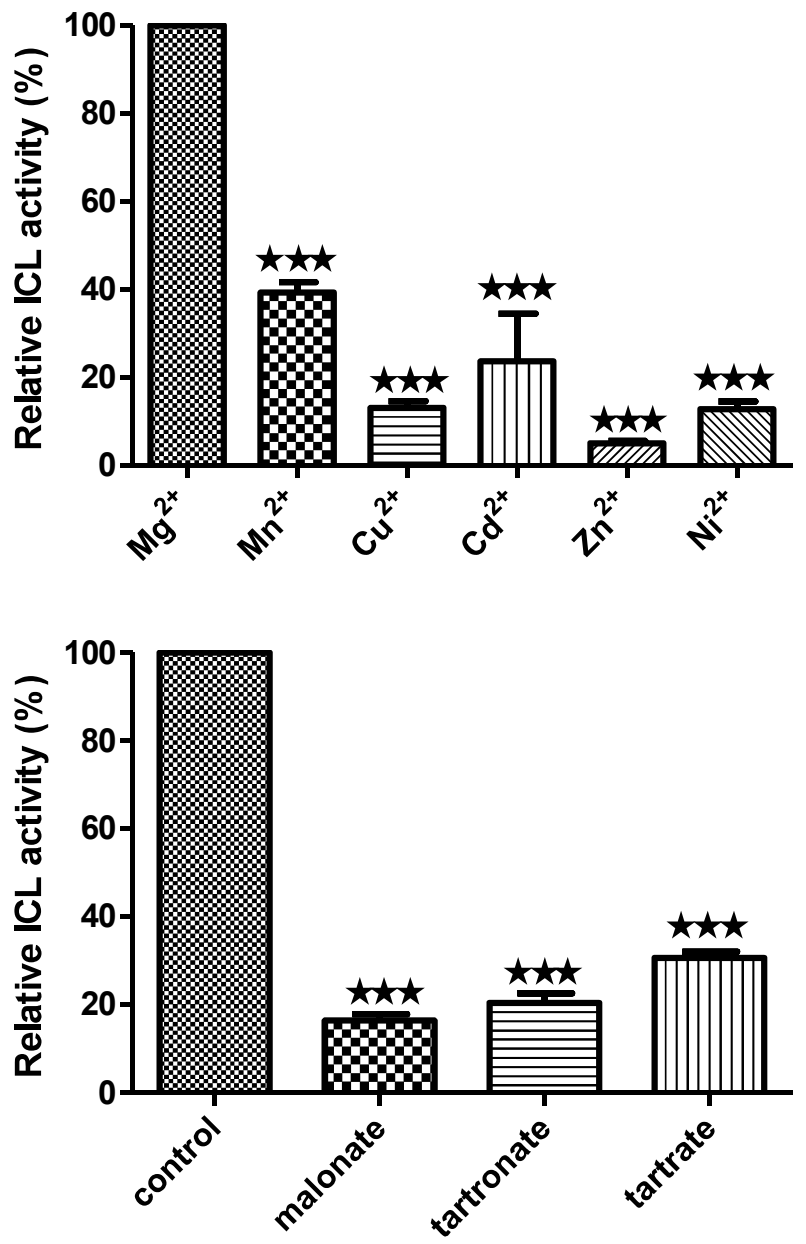

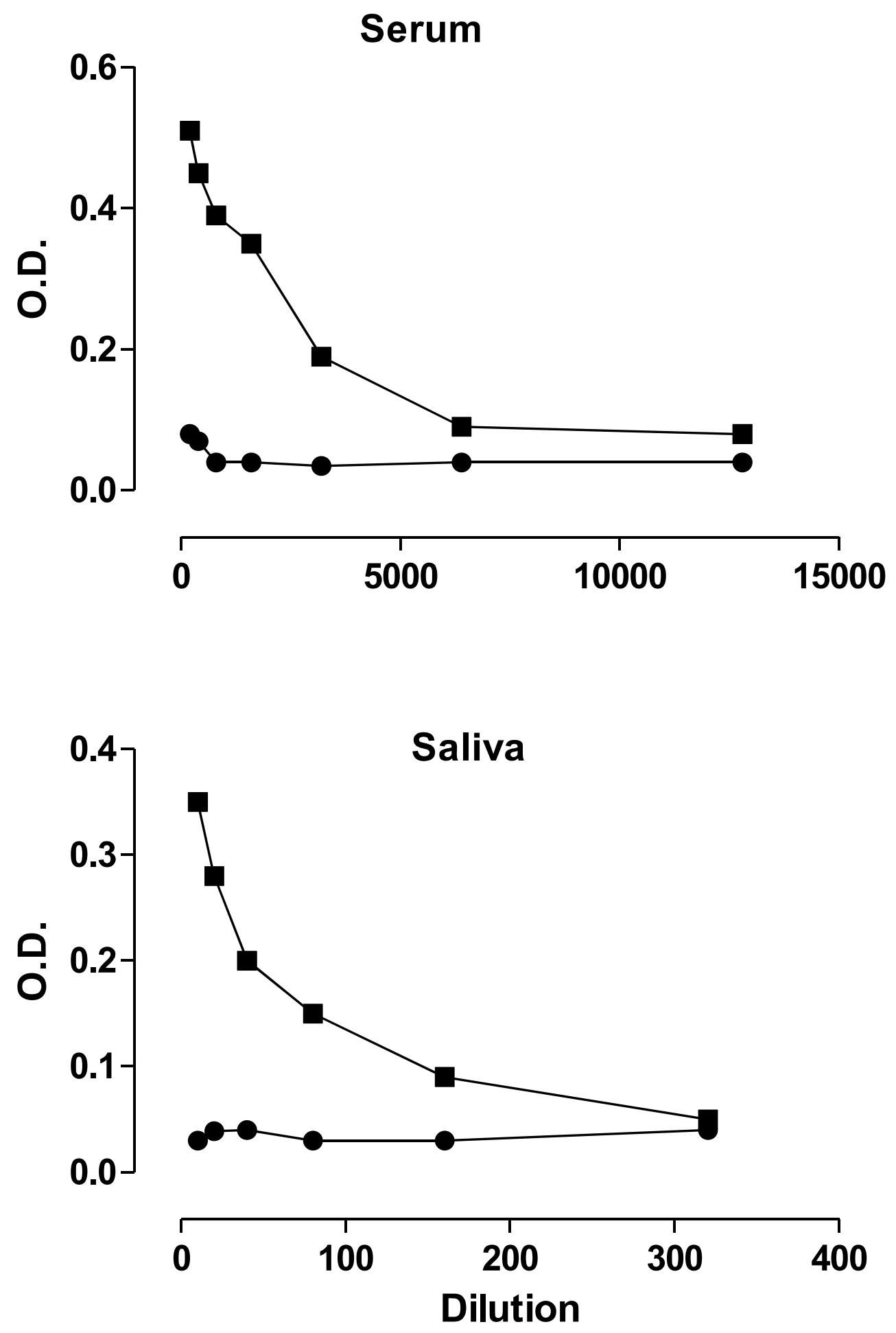


\section{Figures}

Fover,
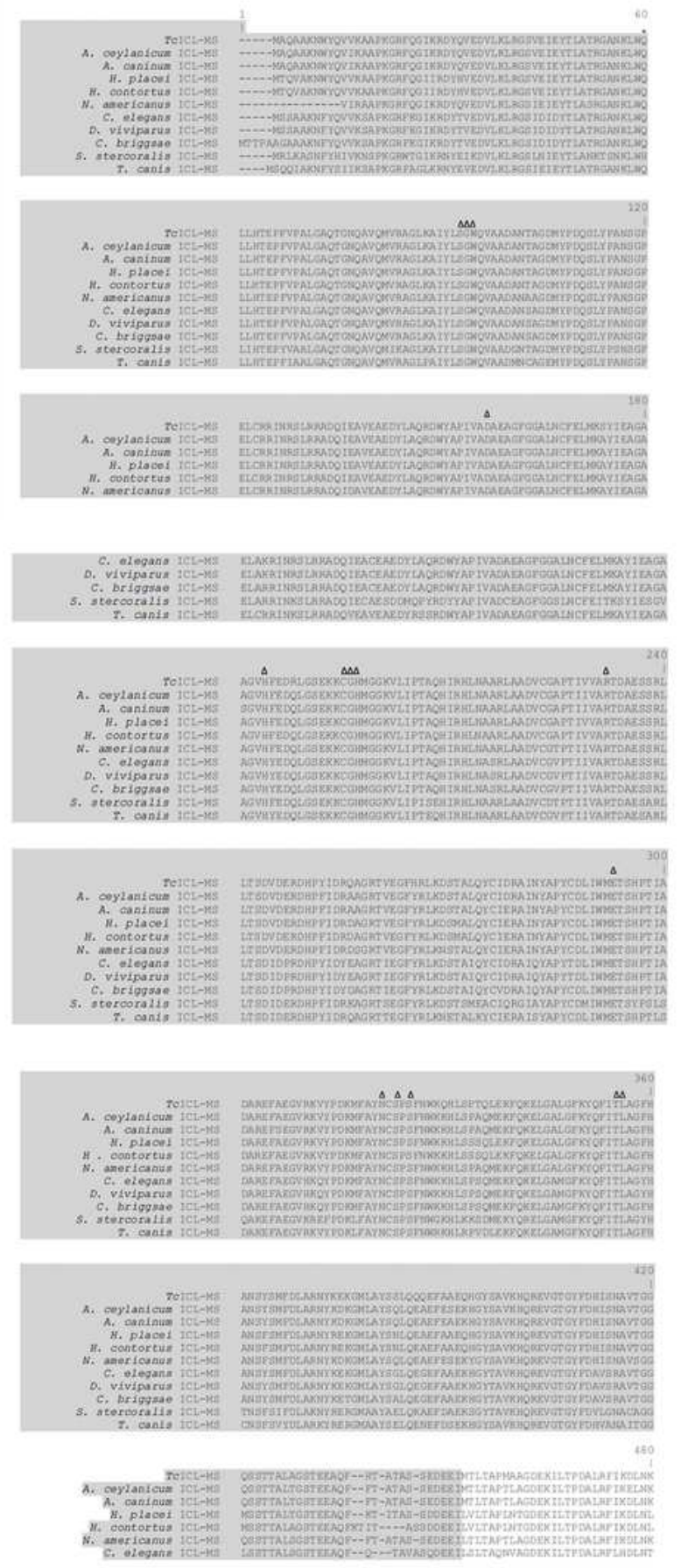
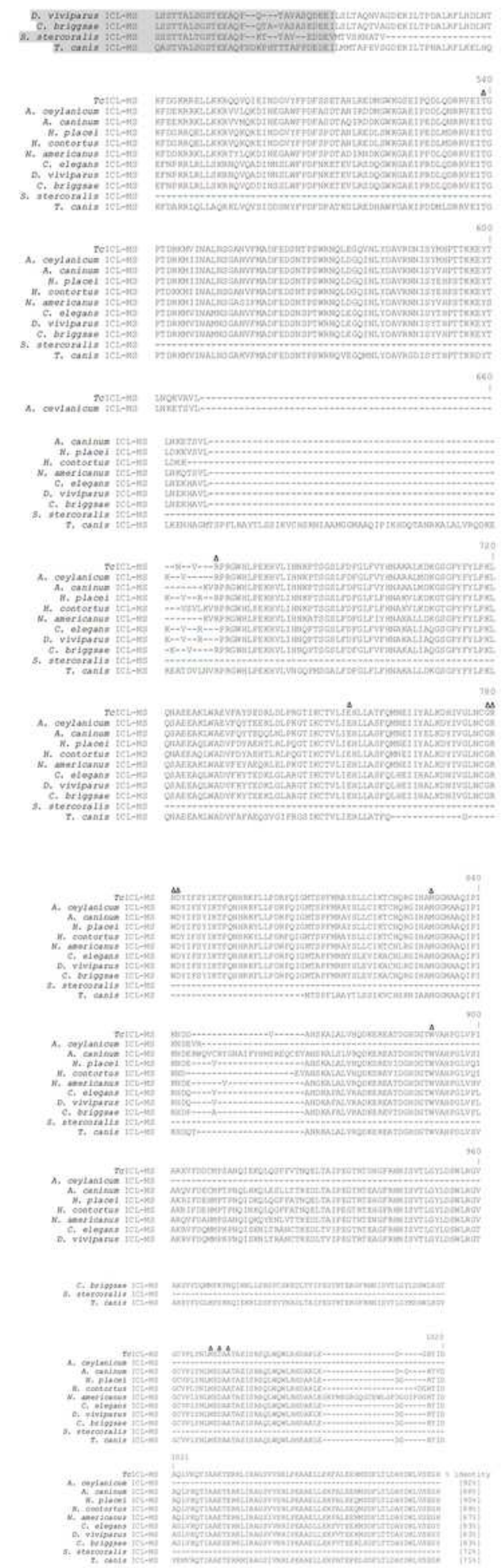

\section{Figure 1}

Multiple protein sequence alignment of TcilCL-MS, Ancylostoma ceylanicum ICL-MS (Gl: AB031935), Ancylostoma caninum ICL-MS (Gl: ABU68338), Haemonchus placei ICL-MS (GI: VD027591.1), Haemonchus contortus ICL-MS (GI: CDL95172.1), Necator americanus ICL-MS (GI: XP_013301212.1), 
Caenorhabditis elegans ICL-MS (GI: NP_001256387.1), Dictyocaulus viviparus ICL-MS (GI: KJH51538.1), Caenorhabditis briggsae ICL-MS (GI: CAP39673.2), Strongyloides stercoralis ICL-MS (GI: AAF00535.1) and Toxocara canis ICL-MS (GI: KHN81706.1). Active and ligand binding sites are The amino acid residues in grey represent ICL and the rest MS. The \% homology of each sequence with TcilCL-MS is shown at the end of the alignment.
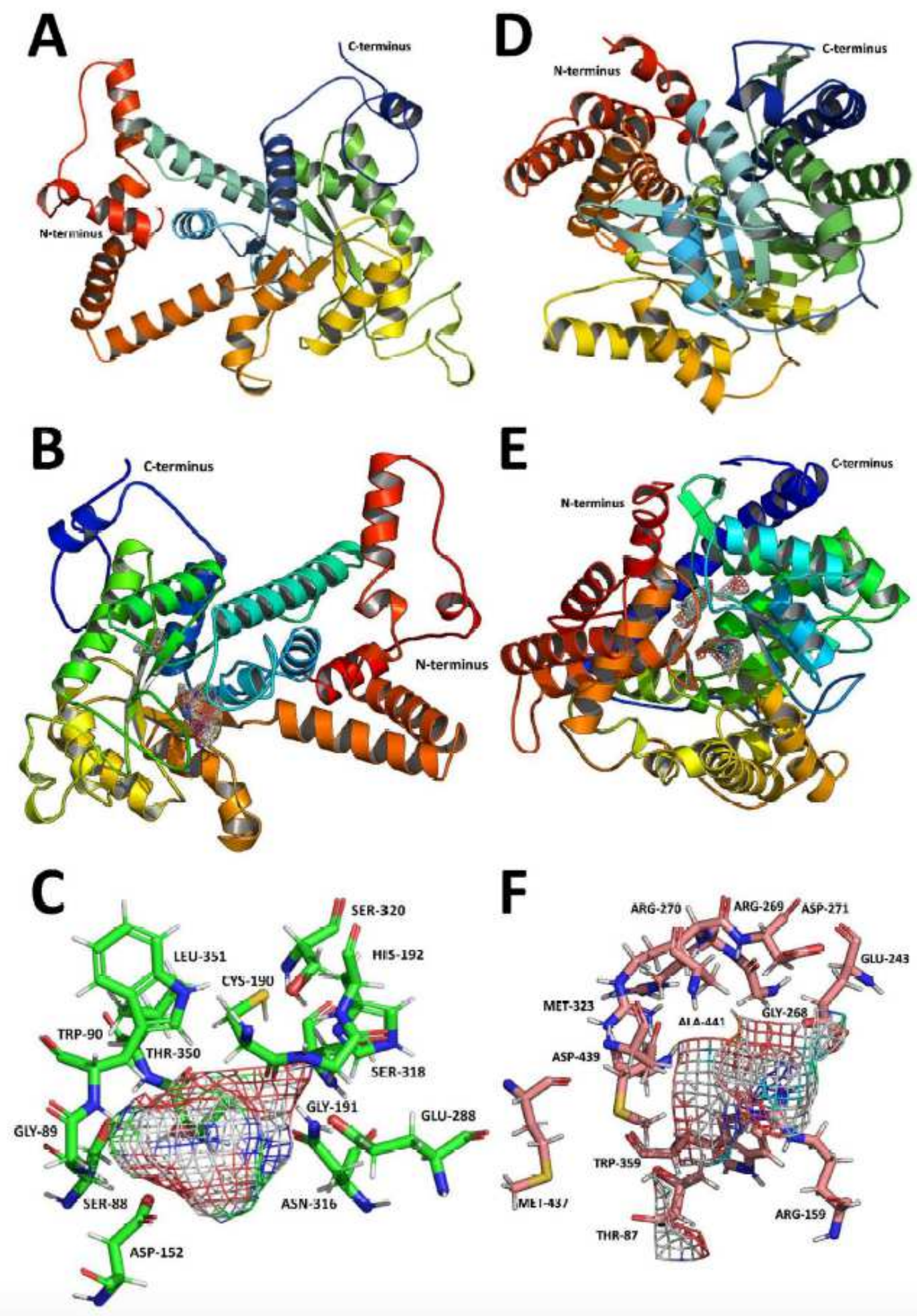

Figure 2 
The predicted tertiary structures of the TcilCL (left) and TciMS (right) monomers. Locations are shown of the $\mathrm{C}$ - and $\mathrm{N}$-terminus in the predicted tertiary structure of TcilCL (A) and TciMS (D). Superposition of the predicted tertiary structures showing the location of the active sites (mesh) within TcilCL (B) and TciMS (E). The active sites of TcilCL are shown in green (C) and TciMS in salmon (F) within $4 \AA$ of the superimposed $3 \mathrm{POX}$ and $3 \mathrm{~S} 9 \mathrm{Z}$ active sites (mesh), respectively.
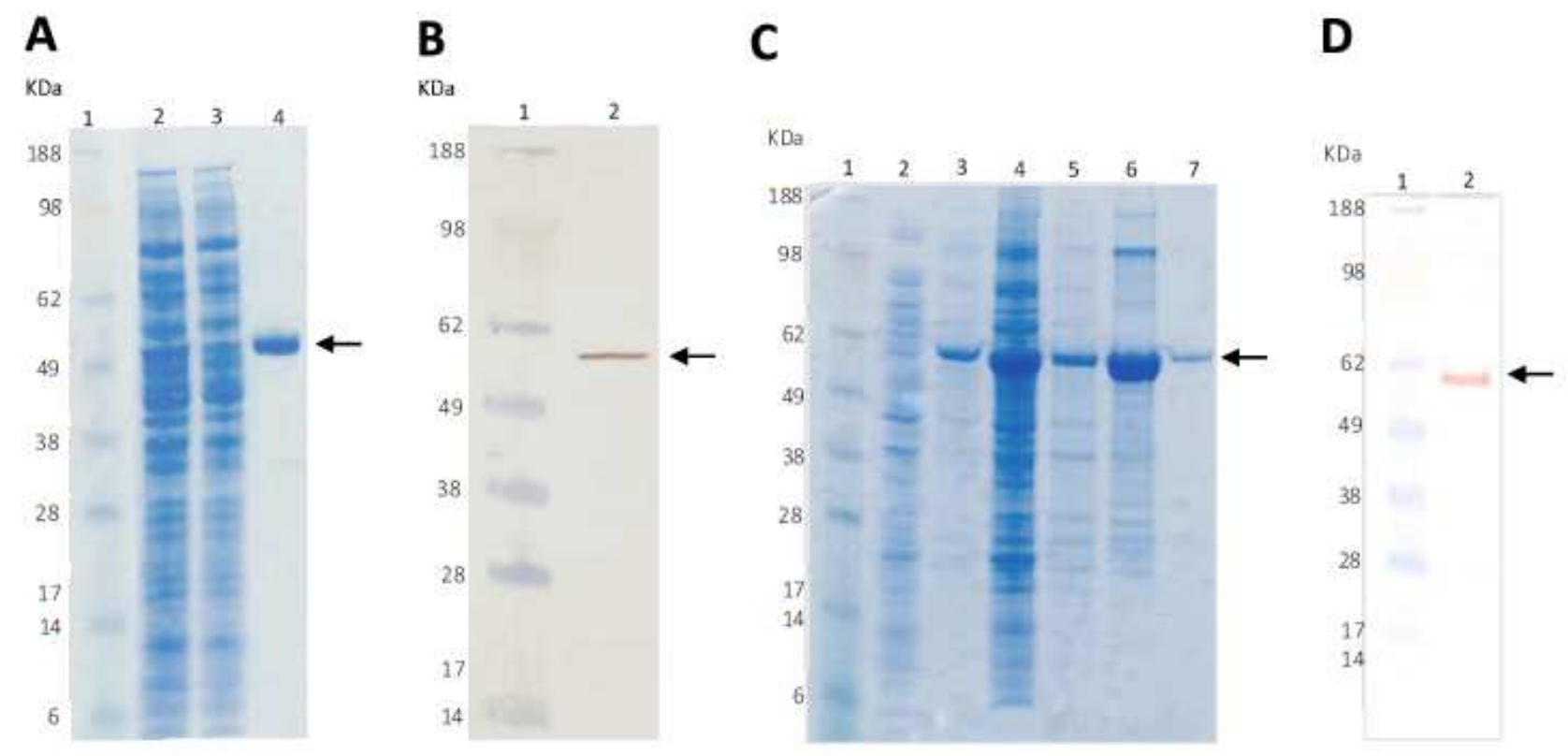

\section{Figure 3}

A: Purified recombinant TcilCL on a NuPageTM $4-12 \%$ Bis-Tris protein gel stained with SimplyBlue safe stain. Lane 1: SeeblueTM plus2 pre-stained protein standard in $\mathrm{kDa}$; Lane 2: filtered soluble bacterial lysate; Lane 3: unbound material; Lane 4: elution fraction ( $1 \mu \mathrm{g}$ of purified recombinant TcilCL indicated by the black arrow). B: Western blot of recombinant purified TcilCL. Lane 1: SeeblueTM plus 2 pre-stained protein standard in $\mathrm{kDa}$; Lane 2: $1 \mu \mathrm{g}$ of recombinant TcilCL detected by a monoclonal anti-polyhistidineperoxidase antibody. C: Purified recombinant TciMS on a $4-12 \%$ Bis-Tris protein gel stained with SimplyBlue safe stain. Lane plus2 pre-stained protein standard in $\mathrm{kDa}$; Lane 2: non-induced fraction; Lane 3: induced fraction; Lane 4: filtered soluble bacterial lysate; Lane 5: solubilised inclusion bodies; Lane 6: elution fraction pre-refolding of purified recombinant TciMS; Lane 7: purified recombinant TciMS. D: Western blot of recombinant purified TciMS. Lane 1: SeeblueTM plus2 pre-stained protein standard in 
$\mathrm{kDa}$; Lane 2: $1 \mu \mathrm{g}$ of recombinant TciMS detected by a monoclonal anti-polyhistidine-peroxidase antibody.

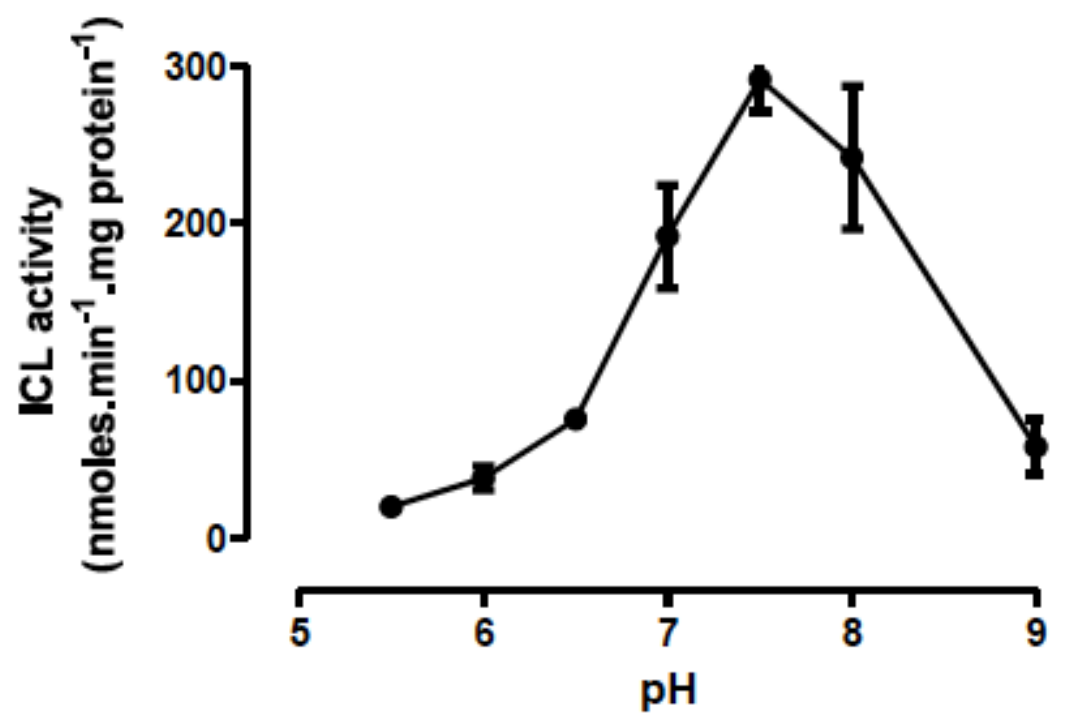

\section{Figure 4}

Effects of $\mathrm{pH}$ on the activity of recombinant TcilCL at $30 \mathrm{oC}$ (mean $\pm \mathrm{SEM}, \mathrm{n}=3$ ). Enzyme activity was measured in a coupled assay in which isocitrate was converted to glyoxylate, which combined with phenyldrazine; the increase in absorption was measured spectrophotometrically at $324 \mathrm{~nm}$. 


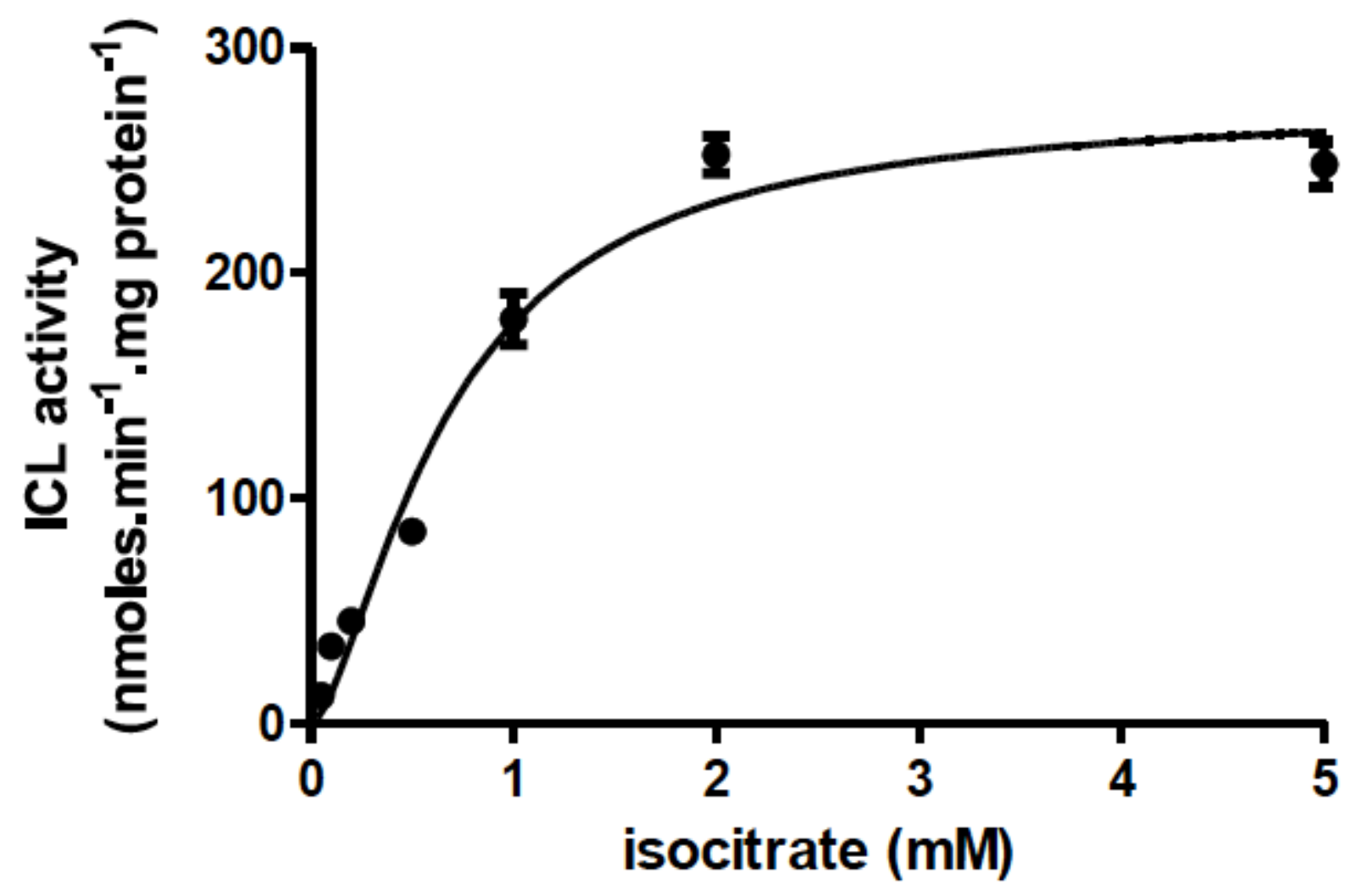

Figure 5

Effects of varying the substrate concentration on the activity of recombinant TcilCL at 30 oC (mean \pm SEM, $n=3$ ). Enzyme activity was measured in a coupled assay in which isocitrate was converted to glyoxylate, which combined with phenyldrazine; the increase in absorption was measured spectrophotometrically at $324 \mathrm{~nm}$. 

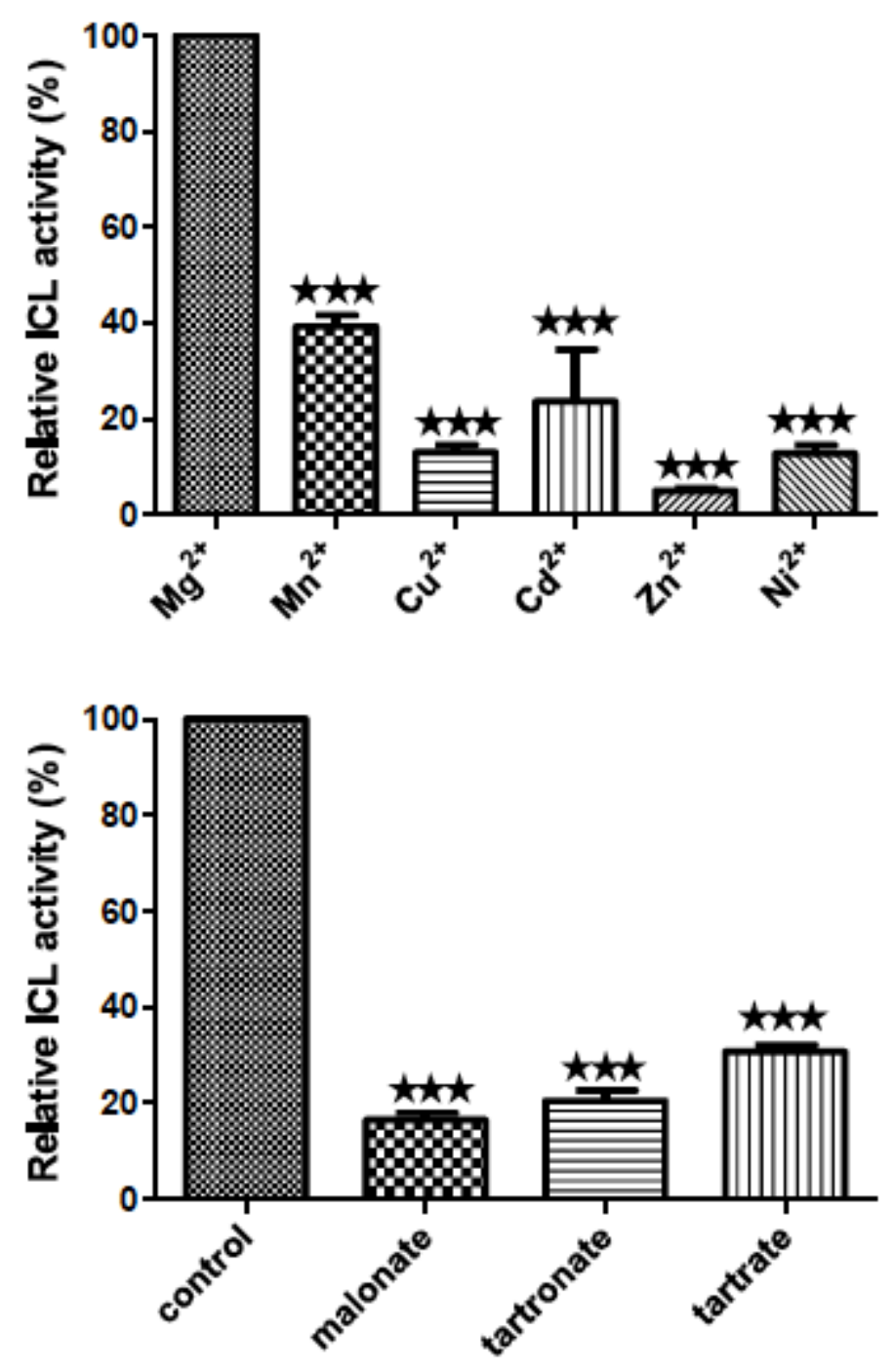

\section{Figure 6}

The effects of bivalent metal ions and potential inhibitors on recombinant TcilCL activity (relative activity, mean $\pm \mathrm{SEM}, \mathrm{n}=3$ ) at $30 \mathrm{oC}$. Enzyme activity was measured in a coupled assay in which isocitrate was converted to glyoxylate, which combined with phenyldrazine; the increase in absorption was measured spectrophotometrically at $324505 \mathrm{~nm}$. 

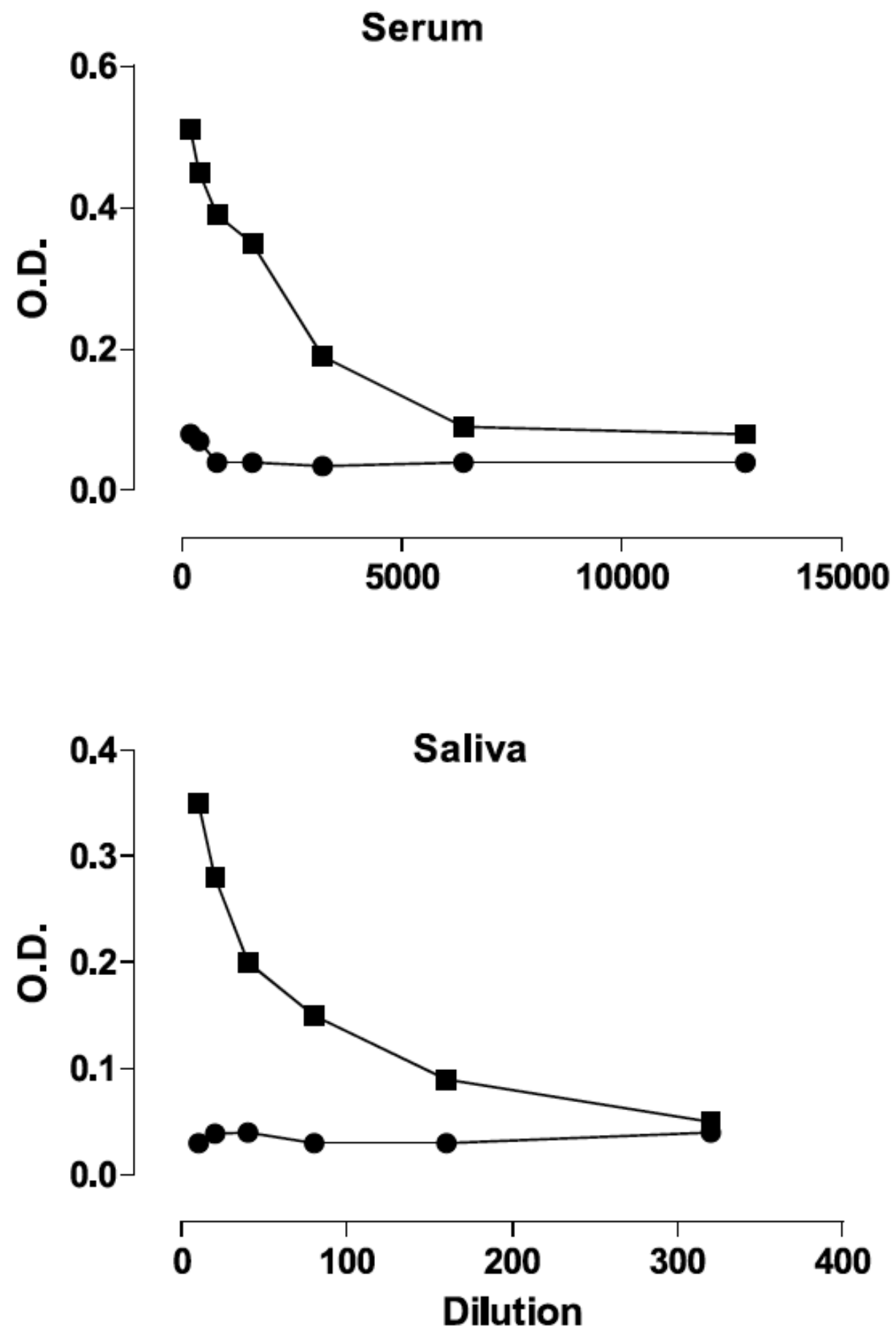

Figure 7

Recognition of recombinant TcilCL by serially diluted immune serum (IgG) (top) 507 or saliva (IgA) (bottom) ( () , but not by parasite-naive serum or saliva ( () . 